\title{
Wpływ pandemii COVID-19 na rynek dłużnych papierów wartościowych - analiza na przykładzie wybranych krajów
}

Małgorzata Mikita*

\section{Streszczenie}

Celem artykułu jest przedstawienie wpływu pandemii COVID-19 na rynki dłużnych papierów wartościowych w siedmiu wybranych krajach europejskich, tj.: Hiszpanii, Francji, Włoszech, Słowacji, Czechach, na Węgrzech i w Polsce. Analiza opiera się na obserwacji danych statystycznych dotyczących dłużnych papierów wartościowych prezentowanych przez Bank Rozrachunków Międzynarodowych. Analizowany jest wskaźnik zadłużenia z tytułu emisji dłużnych papierów wartościowych w wybranych krajach. Okres objęty analizą to rok 2020, czyli okres pandemii COVID-19. W celach porównawczych przytaczane są także dane dotyczące zadłużenia z tytułu emisji dłużnych papierów wartościowych z okresów przed pandemią. Analizie została poddana wielkość zadłużenia z tytułu papierów dłużnych w wybranych krajach w podziale na papiery dłużne emitowane przez korporacje finansowe, korporacje niefinansowe oraz instytucje rządowe i samorządowe. Tendencje w zakresie zmian zadłużenia zostały pokazane także w oparciu o wielkość ogólnego zadłużenia z tytułu papierów dłużnych w omawianych krajach. Aby dokładniej zobrazować zmiany na rynku papierów dłużnych w okresie pandemii COVID-19, wykorzystano dane kwartalne. Analiza tematu pozwala stwierdzić, iż pandemia COVID-19 miała pozytywny wpływ na rozwój rynku papierów dłużnych w omawianych krajach.

\footnotetext{
* Małgorzata Mikita, doktor, Szkoła Główna Handlowa w Warszawie, Kolegium Gospodarki Światowej, Katedra Rynków Kapitałowych, mmikit@sgh.waw.pl.

(C) by the author, licensee Łódź University - Łódź University Press, Łódź, Poland. This article is an open access article distributed under the terms and conditions of the Creative Commons Attribution license CC BY-NC-ND 4.0 (https://creativecommons.org/licenses/by-nc-nd/4.0/)
} 
We wszystkich krajach można było zaobserwować trend wzrostowy w zakresie wysokości całkowitego zadłużenia z tytułu wyemitowanych papierów dłużnych. Wzrost zadłużenia dotyczył zarówno korporacji finansowych i niefinansowych, jak też instytucji rządowych i samorządowych. Obserwowane trendy nie zależały od poziomu rozwoju gospodarczego kraju czy też stopnia rozwoju rynku papierów dłużnych.

Słowa kluczowe: papiery dłużne, Covid-19, pandemia, Polska, Hiszpania, Francja, Włochy, Czechy, Słowacja, Węgry

JEL: G15, G32

\section{Wstęp}

Pandemia COVID-19 wywarła istotny wpływ na gospodarki wszystkich krajów świata $^{1}$, w tym na rynki finansowe ${ }^{2}$. Pierwsze zachorowania wywołane koronawirusem SARS-CoV-2 miały miejsce w listopadzie 2019 r. w chińskim mieście Wuhan. W Europie wirus pojawił się w styczniu $2020 \mathrm{r}$. we Włoszech, a następnie zaczął się szybko rozprzestrzeniać we wszystkich krajach europejskich. 11 marca 2020 r. Światowa Organizacja Zdrowia (WHO) ogłosiła pandemię COVID-19. Po ogłoszeniu pandemii na wielu rynkach finansowych obserwowano spadki. Ich wyrazem było m.in. ograniczenie emisji dłużnych papierów wartościowych (wysokość zadłużenia $\mathrm{z}$ tytułu dłużnych papierów wartościowych $\mathrm{w}$ wielu krajach na koniec pierwszego kwartału 2020 r. była niższa w porównaniu z czwartym kwartałem 2019 r.). Kolejne miesiące pandemii zaowocowały jednak odwróceniem obserwowanego trendu.

Celem pracy jest przedstawienie wpływu pandemii COVID-19 na rynki dłużnych papierów wartościowych w siedmiu wybranych krajach europejskich,

\footnotetext{
${ }^{1}$ Szerzej na ten temat: T. Ibn-Mohammed, K.B. Mustapha, J.M. Godsell, Z. Adamu, K.A. Babatunde, D.D. Akintade, S.C.L. Koh, A critical review of the impacts of COVID-19 on the global economy and ecosystems and opportunities for circular economy strategie, Resources, Conservation and Recycling, January 2021; A. Brodeur, D. Gray, A. Islam, S. Bhuiyan, A literature review of the economics of Covid-19, IZA DP, No. 13411, Discussion Paper Series, June 2020, https://ftp.iza.org/ dp13411.pdf (dostęp: 3.09.2021); K. Heggen, T.J. Sandset, E.Engebretsen, COVID-19 and sustainable development goals, Bull World Health Organisation, 98(10), 2020.

${ }^{2}$ Szerzej na ten temat: M. Ali, N. Alam, S.A.R Rizvi, Coronavirus (COVID-19) - An epidemic or pandemic for financial markets, J. Behav. Exp. Financ., Sep. 27, 2020; M. A.Khan, K. Z. Abdelmohsen, A. Nassani, S. E. Askar, M. Mo. Q. Abro, A. Kabbani, Financial development during COVID-19 pandemic: the role of coronavirus testing and functional labs, Muhammad Khalid Anser, Financ Innov., 7(1): 9, 2021; M.Topcu, O.S. Gulal, The impact of COVID-19 on emerging stock markets, Finance Research Letters, 2020;36:101691; D.H.B Phan, P.K.Narayan, Country responses and the reaction of the stock market to COVID-19 - a preliminary exposition, Emerg Mark Finance Trade, 56(10), 2020.
} 
tj.: Hiszpanii, Francji, Włoszech, Słowacji, Czechach, na Węgrzech i w Polsce. Trzy pierwsze kraje (Hiszpania, Francja, Włochy) to kraje wysoko rozwinięte. Cztery kolejne (Czechy, Słowacja, Węgry i Polska) należą do grupy krajów rozwijających się. Kraje zakwalifikowane do próby badawczej odznaczają się różnym poziomem rozwoju rynku papierów dłużnych. Pozycję lidera zajmuje Francja (kraj ten odznacza się najwyższym wskaźnikiem zadłużenia z tytułu papierów dłużnych do PKB). Na ostatnim miejscu w omawianej grupie (w rankingu poziomu rozwoju rynku papierów dłużnych) plasuje się Polska (wskaźnik zadłużenia z tytułu papierów dłużnych do PKB jest najniższy). Wybór krajów do analizy podyktowany był z jednej strony chęcią zbadania wpływu pandemii COVID-19 na różne kraje europejskie, a $\mathrm{z}$ drugiej zwróceniem uwagi na to, czy wpływ ten był zróżnicowany w zależności od poziomu rozwoju gospodarczego kraju czy też poziomu rozwoju rynku papierów dłużnych.

Analiza opiera się na danych statystycznych dotyczących dłużnych papierów wartościowych prezentowanych przez Bank Rozrachunków Międzynarodowych (Bank for International Settlements - BIS) ${ }^{3}$. Analizowany jest wskaźnik zadłużenia z tytułu emisji dłużnych papierów wartościowych w wybranych krajach. Okres objęty analizą to rok 2020, czyli okres pandemii COVID-19. W celach porównawczych przytaczane są także dane dotyczące zadłużenia z tytułu emisji dłużnych papierów wartościowych z okresów przed pandemią. Analizie została poddana wielkość zadłużenia $\mathrm{z}$ tytułu papierów dłużnych $\mathrm{w}$ wybranych krajach $\mathrm{w}$ podziale na papiery dłużne emitowane przez korporacje finansowe, korporacje niefinansowe oraz instytucje rządowe i samorządowe. Tendencje w zakresie zmian zadłużenia zostały pokazane także w oparciu o wielkość ogólnego zadłużenia z tytułu papierów dłużnych w omawianych krajach. Aby dokładniej zobrazować zmiany na rynku papierów dłużnych w okresie pandemii COVID-19, wykorzystano dane kwartalne.

Podstawowa teza pracy brzmi następująco: pandemia COVID-19 miała pozytywny wpływ na rozwój rynku papierów dłużnych w omawianych krajach.

Praca składa się z trzech części. W pierwszej z nich przybliżono istotę papierów dłużnych. Druga część ukazuje rozwój rynku papierów dłużnych na świecie w okresie ostatnich 20 lat - część ta stanowi tło dla dalszych rozważań. W trzeciej części dokonano analizy wpływu pandemii COVID-19 na rynki papierów dłużnych w Hiszpanii, Francji, Włoszech, Słowacji, Czechach, na Węgrzech i w Polsce. Pracę kończą wnioski wynikające z przeprowadzonej analizy.

\footnotetext{
${ }^{3}$ Źródło danych statystycznych wykorzystanych w artykule: Bank for International Settlements (BIS), Debt securities statistics, www.bis.org/statistics (dostęp: 1.08.2021).
} 


\section{Papiery dłużne - istota}

Papiery dłużne to instrumenty finansowe znane na rynku od wielu lat. Charakter dłużny tych instrumentów oznacza, że ich emitenci są zobowiązani do zwrotu długu w określonym terminie w przyszłości. Do grupy papierów dłużnych przedsiębiorstw zalicza się: obligacje (korporacyjne, skarbowe, komunalne), bony (skarbowe i korporacyjne), skrypty dłużne, jak również papiery wartościowe zabezpieczone aktywami i weksle (Handbook on Securities Statistics 2015, s. 15).

Obligacje to papiery dłużne emitowane w seriach. Emitent plasuje na rynku serię papierów reprezentujących te same prawa majątkowe. Standaryzacja praw dotyczy: charakteru i zakresu świadczeń, jakie przysługują nabywcom obligacji, w tym wysokości i sposobu ustalania oprocentowania, jak również terminu wykupu obligacji. Emitenci obligacji, obok zobowiązania do ich wykupu w przyszłości, zobowiązują się do pełnienia określonego świadczenia na rzecz nabywcy obligacji (obligatariusza). Świadczenie to może mieć charakter pieniężny lub niepieniężny. W przypadku świadczenia pieniężnego emitent obligacji jest zobowiązany do wypłaty obligatariuszom określonego dochodu (najczęściej w formie odsetek) oraz wykupu obligacji w terminie ich zapadalności. W przypadku świadczenia niepieniężnego emitent proponuje obligatariuszom inne świadczenie. Częstym rozwiązaniem $\mathrm{w}$ tym przypadku jest emisja obligacji z prawem do udziału w zysku emitenta, emisja obligacji zamiennych na akcje czy też emisja obligacji z prawem pierwszeństwa. Obligacje mogą być emitowane na okres do jednego roku (obligacje krótkoterminowe), jak również okresy dłuższe (obligacje średnioi długoterminowe) (Kołuda 2015, s. 8). Emitentami obligacji są przedsiębiorstwa (finansowe oraz niefinansowe), a także instytucje rządowe i samorządowe.

Bony to papiery dłużne o charakterze krótkoterminowym (najczęściej spotykane bony to bony o trzymiesięcznym terminie wykupu). Bony sprzedawane są z dyskontem, co oznacza, iż cena ich sprzedaży jest niższa od ceny ich wykupu (różnica między cenami stanowi zysk nabywcy bonów). Emisje bonów komercyjnych mają charakter niepubliczny i przeprowadzane są przez agentów emisji na zlecenie emitenta. Rolę agentów pełnią zazwyczaj banki lub biura maklerskie. Bony mogą być przedmiotem obrotu na rynkach wtórnych.

Papiery wartościowe zabezpieczone aktywami to papiery wyemitowane w oparciu o wyodrębnione aktywa przedsiębiorstwa (najczęściej w procesie sekurytyzacji). Emitentami tego typu papierów są najczęściej tzw. spółki celowe, tzn. spółki powołane wyłącznie w celu przeprowadzenia emisji.

Skrypty dłużne emitowane przez przedsiębiorstwa to średnio- lub długoterminowe papiery wartościowe. Okres ich ważności wynosi zazwyczaj od 1 roku do 10 lat. $Z$ reguły nie są zabezpieczone, a emisja nie jest gwarantowana, co oznacza, że ryzyko nieuplasowania emisji ponosi emitent. Wartość pojedynczej emisji jest najczęściej niższa niż w przypadku emisji obligacji. Mogą być przedmiotem 
obrotu giełdowego lub pozagiełdowego. Obroty pozagiełdowe organizowane są przez agentów emisyjnych, którymi są zazwyczaj banki.

Weksle to dłużne papiery wartościowe, które dają posiadaczom bezwarunkowe prawo do otrzymania określonych kwot pieniężnych w sprecyzowanym terminie w przyszłości. Najczęściej mają charakter krótkoterminowy i są emitowane $\mathrm{z}$ dyskontem w stosunku do wartości nominalnej. Mogą być przedmiotem obrotu na zorganizowanych rynkach finansowych.

Emisja dłużnych papierów wartościowych pozwala emitentowi na pozyskanie kapitału na krótki lub długi okres, w zależności od jego potrzeb. Korporacje finansowe i niefinansowe najczęściej korzystają z tej formy finansowania, gdy potrzebują kapitału na rozwój (Choudhry 2004), niemniej może okazać się również skuteczną formą radzenia sobie z problemami związanymi z utratą płynności finansowej. Trzeba pamiętać, że pozyskanie kapitału zakończy się powodzeniem tylko wtedy, gdy znajdą się podmioty chętne do nabycia wyemitowanych papierów. Nieodzownym warunkiem powodzenia emisji jest zatem przekonanie nabywców do tego, iż papiery, które nabywają, są bezpieczne i przyniosą im zysk w przyszłości. Dla emitentów istotne są koszty emisji i czas, w jakim mogą pozyskać kapitał. Instytucje rządowe i samorządowe dokonują emisji papierów dłużnych najczęściej w celu pozyskania kapitału na realizację inwestycji lub też finansowanie wcześniej zaciągniętego długu (Mysak 2012). Emisja obligacji skarbowych to często wykorzystywany sposób na finansowanie deficytu budżetowego (Somerset 2013).

\section{Rozwój rynku papierów dłużnych na świecie}

Analiza danych statystycznych obrazujących wielkość zadłużenia z tytułu emisji papierów dłużnych w różnych krajach świata w ciągu ostatnich 20 lat (20002021) pozwala stwierdzić, że papiery dłużne to coraz bardziej popularna forma pozyskiwania kapitału. Przykładowo Wielka Brytania, Kanada, Francja odnotowały w tym czasie ponad 4-krotny wzrost ogólnego zadłużenia z tytułu papierów dłużnych (Wielka Brytania - z 1,6 bln USD w 2000 r. do 7,2 bln USD w 2020 r.; Kanada - z 905,3 mld USD do 3,91 bln USD; Francja - z 1,3 bln USD do 5,5 bln USD). W Stanach Zjednoczonych zarejestrowano ponad 3-krotny wzrost (z 14 bln USD w 2000 r. do 47,2 bln USD w 2020 r.). W Niemczech, Włoszech i Japonii ponad 2-krotny wzrost (Niemcy - z 2,1 bln USD do 4,3 bln USD; Włochy $-\mathrm{z}$ 1,4 bln USD do 3,65 bln USD, Japonia - z 7,3 bln USD do 14,7 bln USD). Jeden z najwyższych wzrostów w zakresie emisji papierów dłużnych odnotowała Australia. W okresie 2000-2020 zarejestrowano w tym kraju ponad 6-krotny wzrost zadłużenia (z 395,8 mld USD w 2000 r. do 2498,4 mld USD w 2020 r.) (BIS 2021). 
Emitenci pozyskują kapitał, dokonując emisji papierów dłużnych zarówno na rynki wewnętrzne, jak również rynki zagraniczne. Szczególnie dużą dynamiką wzrostu odznaczało się w okresie ostatnich 20 lat finansowanie zagraniczne. Całkowite światowe zadłużenie z tytułu emisji dłużnych papierów wartościowych emitowanych na rynki zagraniczne w roku 2020 wynosiło 26,97 bln USD, co stanowiło niemal 6-krotny wzrost w porównaniu z rokiem 2000 (na początku $2000 \mathrm{r}$. zadłużenie zagraniczne $\mathrm{z}$ tytułu papierów dłużnych stanowiło 4,65 bln USD) - rys. 1.

Rysunek 1. Całkowite zadłużenie z tytułu emisji dłużnych papierów wartościowych emitowanych na rynki zagraniczne (w bln USD), 1970-2020

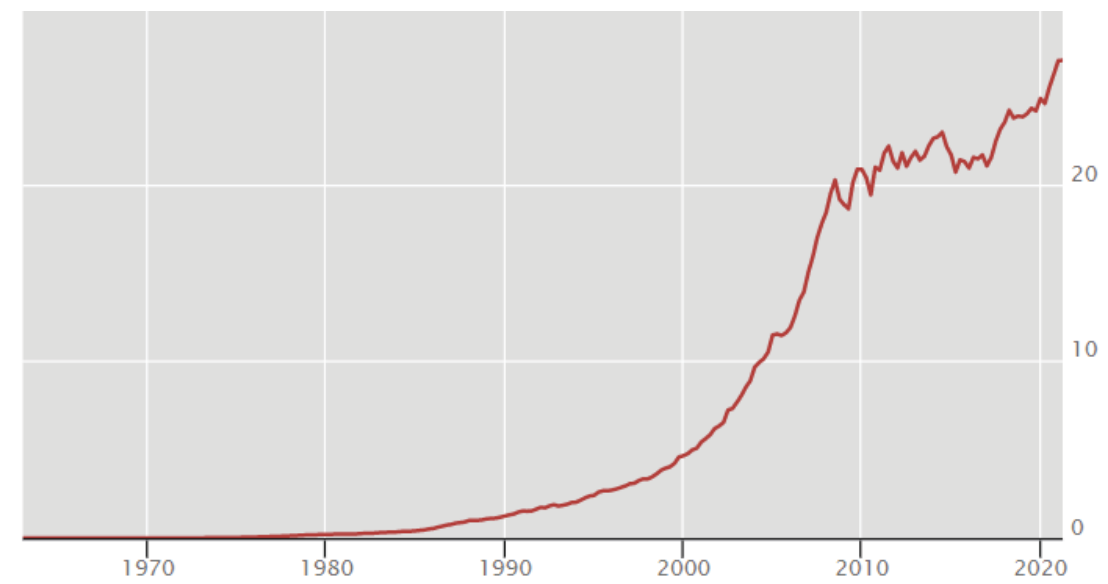

Źródło: Bank for International Settlements (BIS), Debt Securities Statistics, www.bis.org/statistics (data dostępu: 27.10.2021).

Większość emisji dokonywana była przez emitentów z krajów wysoko rozwiniętych. W roku 2020 wielkość zadłużenia zagranicznego z tytułu papierów dłużnych w krajach wysoko rozwiniętych wynosiła 18,569 bln USD, podczas gdy na kraje rozwijające się i rynki wschodzące przypadało zaledwie 2,968 bln USD - rys. 2 i 3. 
Rysunek 2. Całkowite zadłużenie krajów rozwiniętych z tytułu emisji dłużnych papierów wartościowych emitowanych na rynki zagraniczne (w bln USD)

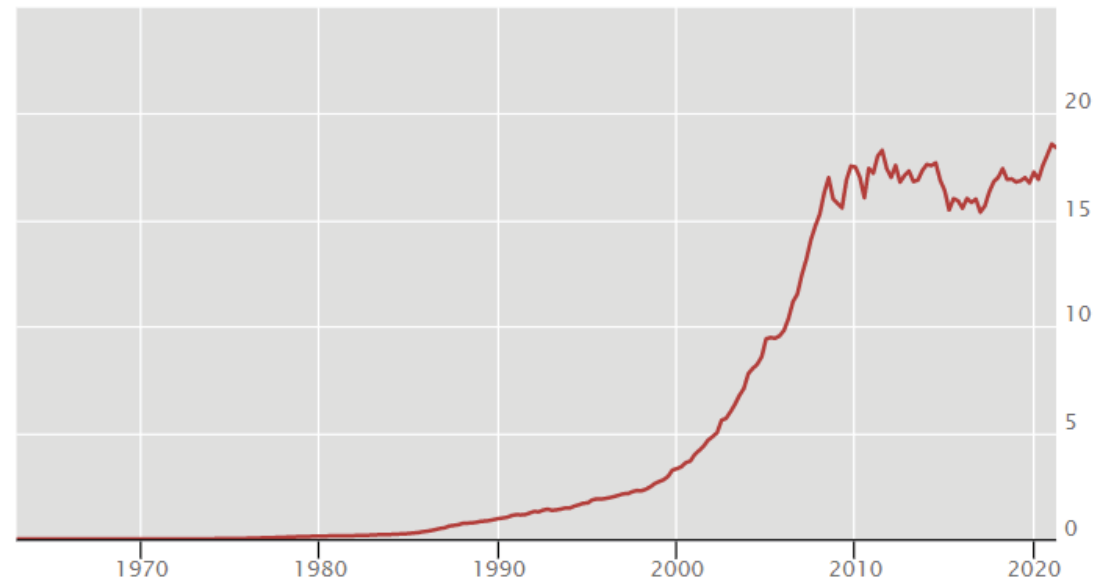

Źródło: Bank for International Settlements (BIS), Debt Securities Statistics, www.bis.org/statistics (data dostępu: 27.10.2021).

Rysunek 3. Całkowite zadłużenie krajów rozwijających się z tytułu emisji dłużnych papierów wartościowych emitowanych na rynki zagraniczne (w bln USD)

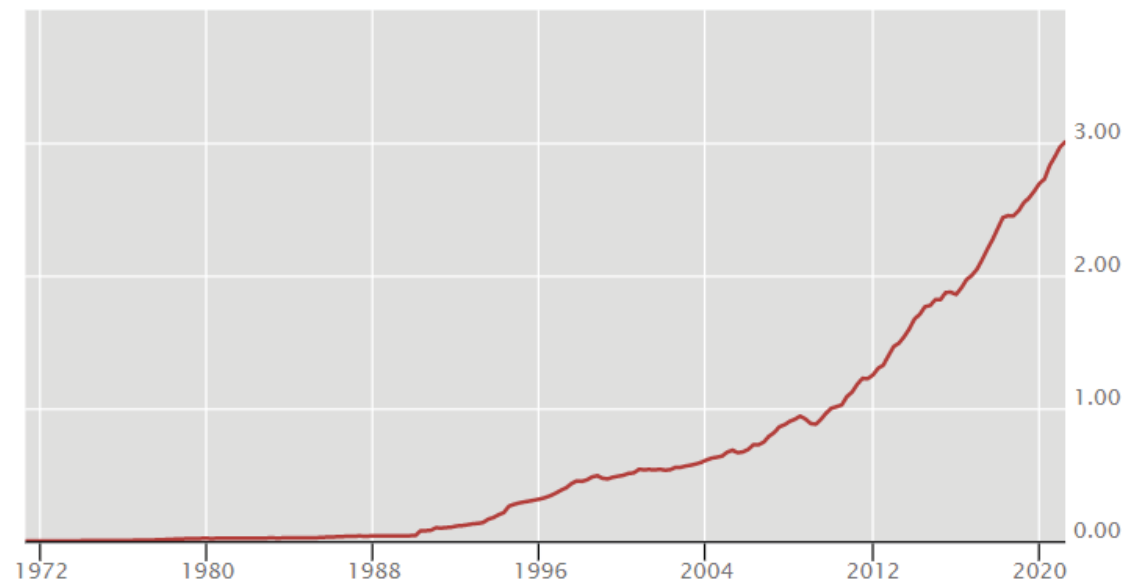

Źródło: Bank for International Settlements (BIS), Debt Securities Statistics, www.bis.org/statistics (data dostępu: 27.10.2021).

Krajem o najwyższym wskaźniku zadłużenia z tytułu emisji dłużnych papierów wartościowych do PKB kraju (w \%) jest Japonia. Wysokość wskaźnika osiąga wartość 2,9. W Polsce wysokość wskaźnika kształtuje się na poziomie zaledwie $0,69-$ tab. 1 . 
Tabela 1. Dłużne papiery wartościowe jako \% PKB, 2020 r.

\begin{tabular}{|l|c|c|c|}
\hline \multicolumn{1}{|c|}{ Kraj } & $\begin{array}{c}\text { Zadłużenie z tytułu } \\
\text { emisji dlużnych } \\
\text { papierów wartościowych } \\
\text { (w mld USD) }\end{array}$ & $\begin{array}{c}\text { PKB } \\
\text { (w mld USD) }\end{array}$ & $\begin{array}{c}\text { Wskaźnik zadłużenia } \\
\text { z tytulu emisji dlużnych } \\
\text { papierów wartościowych } \\
\text { do PKB kraju }\end{array}$ \\
\hline Japonia & 14678 & 5065 & 2,9 \\
\hline Wielka Brytania & 7172 & 2708 & 2,65 \\
\hline Kanada & 3910 & 1643 & 2,38 \\
\hline Stany Zjednoczone & 47237 & 20937 & 2,26 \\
\hline Francja & 5532 & 2603 & 2,1 \\
\hline Włochy & 3650 & 1886 & 1,9 \\
\hline Australia & 2498 & 1331 & 1,8 \\
\hline Hiszpania & 2315 & 1281 & 1,1 \\
\hline Niemcy & 4287 & 3806 & 1,0 \\
\hline Czechy & 246 & 244 & 0,9 \\
\hline Węgry & 138 & 155 & 0,7 \\
\hline Słowacja & 75 & 105 & 0,69 \\
\hline Polska & 408 & 594 & \\
\hline
\end{tabular}

Źródło: o pracowanie własne na podstawie danych prezentowanych przez Bank Rozrachunków Międzynarodowych https://stats.bis.org oraz Trading Economics https://tradingeconomics.com (data dostępu: 27.10.2021).

Mimo wyraźnego trendu wzrostowego rynek dłużnych papierów wartościowych, szczególnie rynek papierów komercyjnych, w większości krajów świata pozostaje rynkiem słabo rozwiniętym. Dotyczy to m.in. krajów Unii Europejskiej. Podstawowym źródłem finansowania przedsiębiorstw pozostają nadal kredyty bankowe (European Banking Federation 2019, s. 10). Do zmiany tej sytuacji ma przyczynić się budowa unii rynków kapitałowych (Capital Markets Union - CMU), która obejmie wszystkie kraje członkowskie UE (Rebranding Capital Markets Union. A market finance action plan 2019, s. 9). W ramach unii kapitałowej planuje się m.in. ujednolicenie zasad w zakresie emisji papierów dłużnych (European Commission 2015), co ma ułatwić realizację procesu emisji, jak też skrócić okres przygotowawczy przed emisją. Można spodziewać się także redukcji kosztów związanych z emisją papierów dłużnych (Komisja Europejska 2015). Chociaż proces budowy unii kapitałowej rozpoczął się w 2015 r., projekt ten wciąż nie został ukończony (European Commission 2021). Istotną przeszkodą dla prowadzenia dalszych prac stała się pandemia Covid-19.

Pandemia Covid-19 w bardzo istotny sposób wpłynęła na gospodarki poszczególnych krajów świata i zmusiła rządy i banki centralne (szczególnie EBC i FED) do podjęcia szeregu natychmiastowych działań na rynkach finansowych, których celem było zapewnienie stabilności ich działania (Mccauley 2020). Rządowe programy pomocowe spowodowały, że duże kwoty pieniężne trafiły do różnych podmiotów gospodarczych. Niewątpliwie części z nich zapewniło to przetrwanie na rynku, dla 
części był to jednak dodatkowy „Zastrzyk” gotówki zatrzymany na przyszłość. Można spodziewać się, że część z tych pieniędzy zostanie ulokowana w przyszłości na rynku papierów dłużnych. Banki centralne, skupując obligacje skarbowe i korporacyjne, wpłynęły na przywrócenie zaufania inwestorów do rynku instrumentów dłużnych, co znacznie poprawiło płynność tego rynku (Kargar i in. 2020). Niestety, niepożądanym zjawiskiem z tym związanym w dhuższej perspektywie jest rosnąca inflacja.

W celu przeciwdziałania negatywnym skutkom kryzysu Komisja Europejska zdecydowała o pozostawieniu państwom członkowskim nieulokowanych środków z funduszu spójności, a także przyspieszeniu wydatkowania środków na kolejny rok budżetowy (Szymańska i in. 2020). Poluzowano także zasady dotyczące pomocy publicznej oraz zawieszono obowiązywanie reguł dyscypliny finansowej Paktu Stabilności i Wzrostu. W marcu 2020 r. Europejski Bank Centralny uruchomił interwencyjny program skupu obligacji państw i przedsiębiorstw (Pandemiczny Program Zakupów Awaryjnych - Pandemic Emergency Purchase Programme - PEPP). Na zakup papierów wartościowych sektora prywatnego i publicznego przeznaczono łącznie 750 mld (ECB 2021). Realizacja programu pozwoliła na emisję długu bez narażania się na ryzyko znaczącego wzrostu oprocentowania obligacji (Szymańska $i$ in. 2020). Wiele banków centralnych w różnych krajach samodzielnie uruchomiło programy skupu obligacji emitowanych w walutach krajowych, co pozwoliło na odbudowanie zaufania inwestorów do rynku papierów dłużnych (Arslan i in. 2020).

Widocznym efektem krótkoterminowym pandemii COVID-19 jest gwałtowny wzrost emisji długu publicznego, a także wzrost zadłużenia przedsiębiorstw. Można spodziewać się utrzymania tego trendu w przyszłości (Hördahl i in. 2020). Szczególnie dynamicznego rozwoju można spodziewać się na rynku międzynarodowych papierów dłużnych emitowanych przez korporacje niefinansowe (Aldasoro i in. 2021). Dużą dynamikę wzrostów obserwuje się na tym rynku od roku 2000 (BIS Statistics 2021). Również w trakcie pandemii, w roku 2020, trend ten był kontynuowany. Chociaż całkowite zadłużenie korporacji niefinansowych z tytułu zagranicznych emisji papierów dłużnych na świecie jest ponad czterokrotnie mniejsze niż zadłużenie korporacji finansowych, to jednak można oczekiwać zmniejszenia się tych dysproporcji w przyszłości.

Pandemia Covid-19 i działania podejmowane przez rządy i banki centralne miały istotny wpływ na kształtowanie się sytuacji na rynku dłużnych papierów wartościowych. W przypadku Hiszpanii, Francji, Włoszech, Słowacji, Czech, Węgier i Polski możemy mówić o wpływie pozytywnym. 


\section{Wpływ pandemii COVID-19 na rynki dłużnych papierów wartościowych w Hiszpanii, Francji, Włoszech, Czechach, Słowacji, na Węgrzech i w Polsce}

Pandemia COVID-19 w istotny sposób wpłynęła na rynki papierów dłużnych w Hiszpanii, Francji, Włoszech, Czechach, Słowacji, na Węgrzech i w Polsce, powodując zarówno wzrosty, jak i spadki wysokości zadłużenia. Przeprowadzona poniżej analiza opiera się na danych statystycznych dotyczących dłużnych papierów wartościowych prezentowanych przez Bank Rozrachunków Międzynarodowych (Bank for International Settlements - BIS) ${ }^{4}$. Analizowany jest wskaźnik zadłużenia z tytułu emisji dłużnych papierów wartościowych w wybranych krajach. Okres objęty analizą to rok 2020, czyli okres pandemii COVID-19, jednak w celach porównawczych przytaczano także dane dotyczące zadłużenia z tytułu emisji dłużnych papierów wartościowych z okresów przed pandemią. Analizie została poddana wielkość zadłużenia z tytułu papierów dłużnych w wybranych krajach w podziale na papiery dłużne emitowane przez korporacje finansowe, korporacje niefinansowe oraz instytucje rządowe i samorządowe. Tendencje w zakresie zmian zadłużenia zostały pokazane także w oparciu o wielkość ogólnego zadłużenia z tytułu papierów dłużnych w omawianych krajach. Aby dokładniej zobrazować zmiany na rynku papierów dłużnych w okresie pandemii COVID-19, wykorzystano dane kwartalne.

\section{Wpływ pandemii COVID-19 na rynki dłużnych papierów wartościowych w Hiszpanii}

Zadłużenie z tytułu emisji dłużnych papierów wartościowych w Hiszpanii na koniec 2020 r. wynosiło 2314,6 mld USD, co stanowiło wzrost w stosunku do pierwszego kwartału 2020 r. o 361,9 mld USD - tab. 2.

Tabela 2. Zadłużenie z tytułu emisji dłużnych papierów wartościowych w Hiszpanii (w mld USD), 2019-2020

\begin{tabular}{|l|c|c|c|c|c|c|c|c|}
\cline { 2 - 9 } \multicolumn{1}{c|}{} & Q1 19 & Q2 19 & Q3 19 & Q4 19 & Q1 20 & Q2 20 & Q3 20 & Q4 20 \\
\hline $\begin{array}{l}\text { Zadłużenie korporacji } \\
\text { finansowych }\end{array}$ & 651,2 & 649,1 & 630,9 & 665,8 & 645,9 & 685,7 & 710,4 & 710,9 \\
\hline $\begin{array}{l}\text { Zadłużenie korporacji } \\
\text { niefinansowych }\end{array}$ & 124,2 & 129,4 & 129,3 & 132,4 & 128,6 & 136,8 & 145,5 & 155,5 \\
\hline $\begin{array}{l}\text { Zadłużenie instytucji } \\
\text { rządowych i samo- } \\
\text { rądowych }\end{array}$ & 1181,9 & 1204,6 & 1149,7 & 1174,8 & 1178,2 & 1276,2 & 1356,3 & 1448,1 \\
\hline Zadłużenie - ogółem & 1957,9 & 1983,0 & 1909,9 & 1973,0 & 1952,7 & 2098,7 & 2212,2 & 2314,6 \\
\hline
\end{tabular}

Źródło: Bank for International Settlements (BIS), Debt Securities Statistics, www.bis.org/statistics (data dostępu: 27.10.2021).

${ }^{4}$ Źródło danych statystycznych wykorzystanych w artykule: Bank for International Settlements (BIS), Debt securities statistics, www.bis.org/statistics (dostęp: 1.08.2021). 
W okresie pandemii COVID-19, w roku 2020, można było obserwować trend wzrostowy w zakresie wysokości całkowitego zadłużenia z tytułu wyemitowanych papierów dłużnych, co oznacza, że z kwartału na kwartał zadłużenie rosło - rys. 4.

Rysunek 4. Całkowite zadłużenie z tytułu emisji dłużnych papierów wartościowych w Hiszpanii (w mld USD), 2020

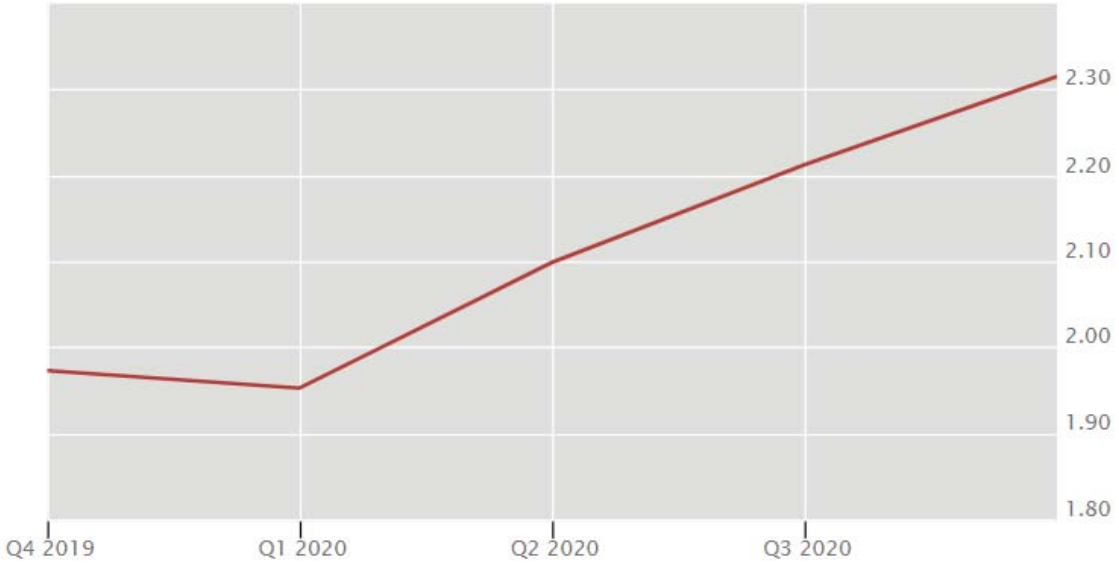

Źródło: Bank for International Settlements (BIS), Debt Securities Statistics, www.bis.org/statistics (data dostępu: 27.10.2021).

Wzrost zadłużenia dotyczył zarówno korporacji finansowych i niefinansowych, jak i instytucji rządowych i samorządowych - rys. 5, 6 i 7.

Rysunek 5. Zadłużenie korporacji finansowych z tytułu emisji dłużnych papierów wartościowych w Hiszpanii (w mld USD), 2020

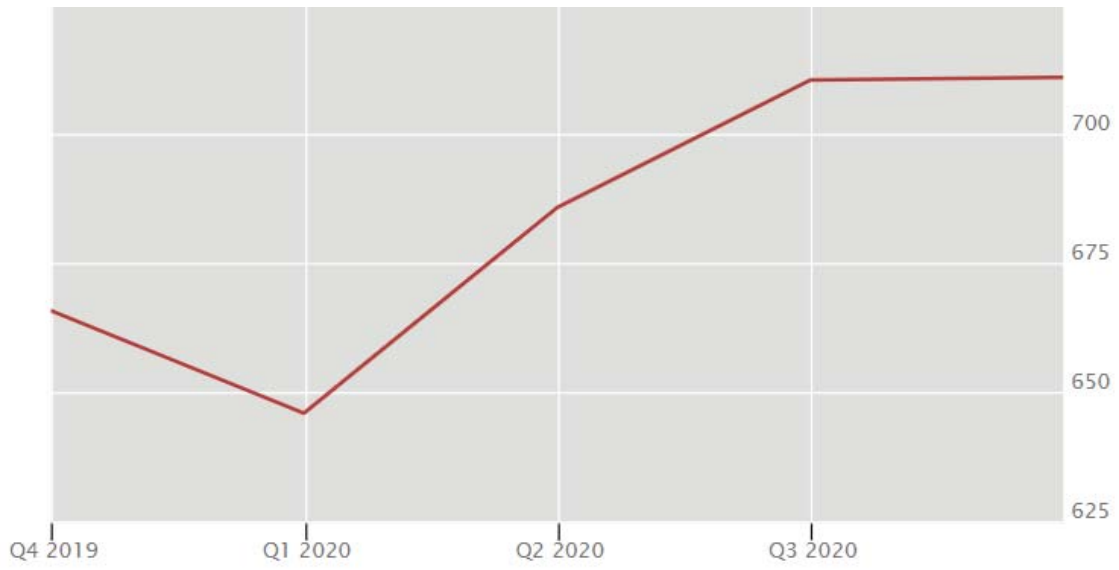

Źródło: Bank for International Settlements (BIS), Debt Securities Statistics, www.bis.org/statistics (data dostępu: 27.10.2021). 
Rysunek 6. Zadłużenie korporacji niefinansowych z tytułu emisji dłużnych papierów wartościowych w Hiszpanii (w mld USD), 2020

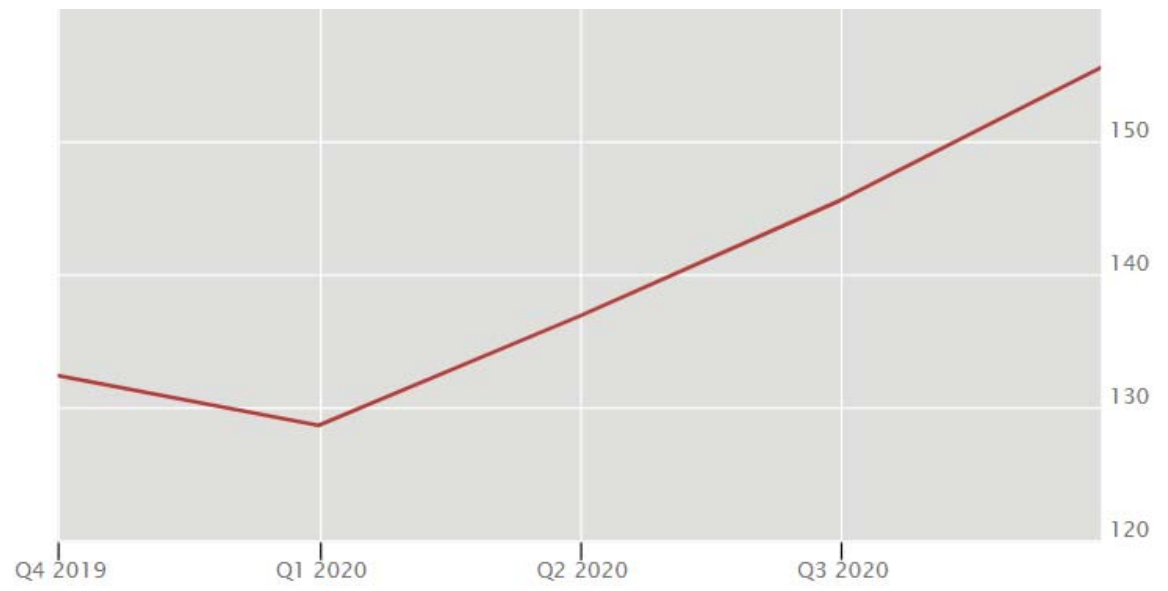

Źródło: Bank for International Settlements (BIS), Debt Securities Statistics, www.bis.org/statistics (data dostępu: 27.10.2021).

Rysunek 7. Zadłużenie instytucji rządowych i samorządowych z tytułu emisji dłużnych papierów wartościowych w Hiszpanii (w trylionach USD), 2020



Źródło: Bank for International Settlements (BIS), Debt Securities Statistics, www.bis.org/statistics (data dostępu: 27.10.2021).

Przed wybuchem pandemii, tj. w roku 2019, trend wzrostowy nie był tak wyraźny. W trzecim kwartale 2019 r. ogólne zadłużenie z tytułu wyemitowanych papierów dłużnych spadło w stosunku do drugiego kwartału 2019 r., do czego przyczyniło się zmniejszenie emisji papierów dłużnych zarówno przez korporacje, jak też instytucje rządowe i samorządowe. 
Rynek papierów dłużnych w Hiszpanii rozwija się od początku lat 90. XX w. Obecnie (wg danych za 2020 r.) wskaźnik zadłużenia z tytułu emisji dłużnych papierów wartościowych do PKB kraju wynosi 1,8. Szczególnie duże tempo rozwoju tego rynku można było obserwować w latach 2002-2008. W drugim kwartale 2011 r. zadłużenie z tytułu emisji dłużnych papierów wartościowych osiągnęło najwyższą wartość w swojej historii, tj. 2,5 bln USD. W czwartym kwartale 2016 r. nastąpił spadek zadłużenia do 1,46 bln USD. Pandemia Covid-19 wyraźnie pobudziła rozwój tego rynku - rys. 8 .

Rysunek 8. Całkowite zadłużenie z tytułu emisji dłużnych papierów wartościowych w Hiszpanii (w bln USD), 1990-2020

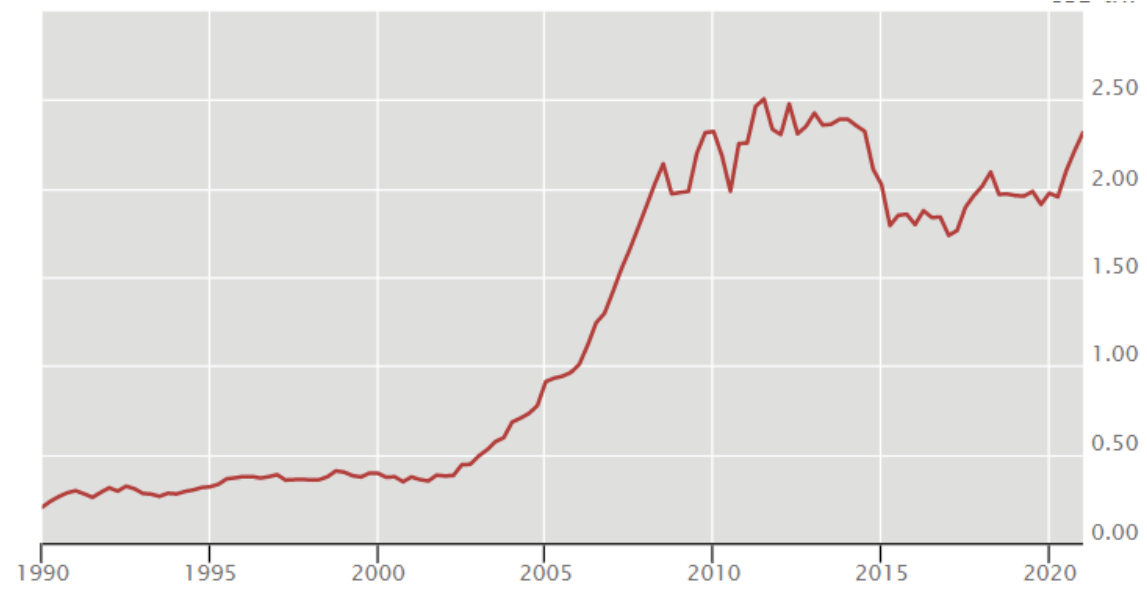

Źródło: Bank for International Settlements (BIS), Debt Securities Statistics, www.bis.org/statistics (data dostępu: 27.10.2021).

\section{Wpływ pandemii COVID-19 na rynki dłużnych papierów wartościowych we Francji}

Pod koniec 2020 r. Francja odnotowała zadłużenie z tytułu emisji dłużnych papierów wartościowych na poziomie 5532,4 mld USD. Wynik ten stanowił wzrost w stosunku do pierwszego kwartału 2020 r. o 877,6 mld USD - tab. 3.

Można było obserwować trend wzrostowy w zakresie wysokości całkowitego zadłużenia z tytułu wyemitowanych papierów dłużnych - rys. 9. 
Tabela 3. Zadłużenie z tytułu emisji dłużnych papierów wartościowych we Francji (w mld USD), 2019-2020

\begin{tabular}{|l|c|c|c|c|c|c|c|c|}
\hline & Q1 19 & Q2 19 & Q3 19 & Q4 19 & Q1 20 & Q2 20 & Q3 20 & Q4 20 \\
\hline $\begin{array}{l}\text { Zadłużenie korporacji } \\
\text { finansowych }\end{array}$ & 1639,1 & 1683,7 & 1629,0 & 1679,3 & 1644,5 & 1733,4 & 1758,8 & 1856,1 \\
\hline $\begin{array}{l}\text { Zadłużenie korporacji } \\
\text { niefinansowych }\end{array}$ & 676,1 & 689,6 & 687,9 & 697,3 & 701,1 & 777,5 & 823,4 & 847,0 \\
\hline $\begin{array}{l}\text { Zadłużenie instytucji } \\
\text { rządowych i samo- } \\
\text { rąadowych }\end{array}$ & 2280,1 & 2316,4 & 2262,7 & 2291,5 & 2309,1 & 2565,2 & 2727,7 & 2829,2 \\
\hline Zadłużenie - ogółem & 4595,3 & 4689,7 & 4579,6 & 4668,1 & 4654,8 & 5076,2 & 5309,9 & 5532,4 \\
\hline
\end{tabular}

Źródło: Bank for International Settlements (BIS), Debt Securities Statistics, www.bis.org/statistics (data dostępu: 27.10.2021).

Rysunek 9. Całkowite zadłużenie z tytułu emisji dłużnych papierów wartościowych we Francji (w bln USD), 2020

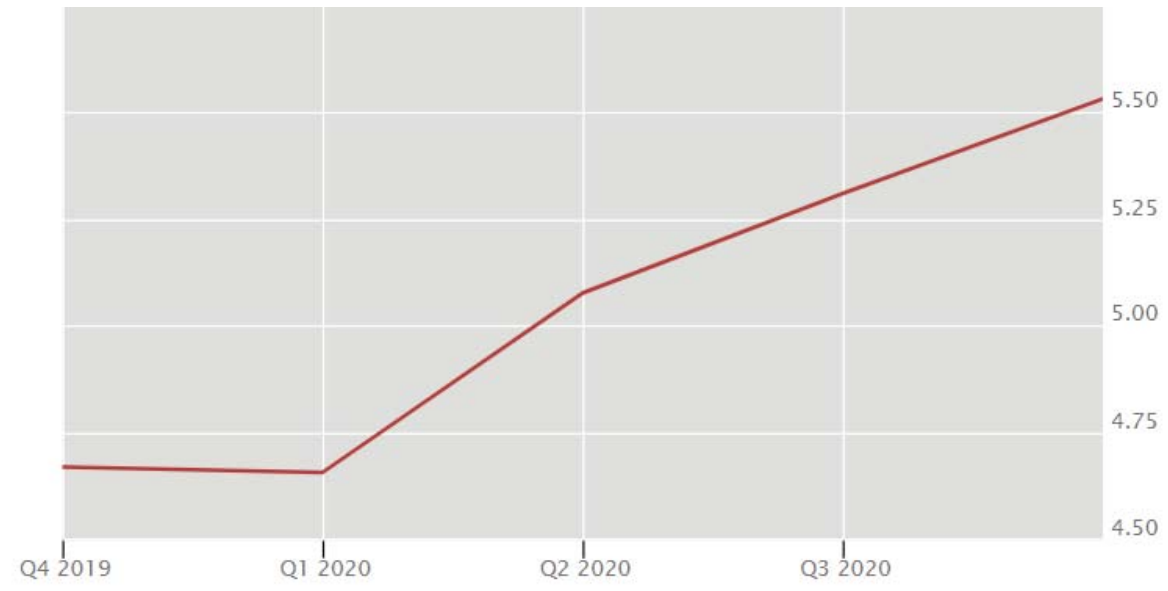

Źródło: Bank for International Settlements (BIS), Debt Securities Statistics, www.bis.org/statistics (data dostępu: 27.10.2021).

Wzrost zadłużenia dotyczył zarówno korporacji finansowych i niefinansowych, jak również instytucji rządowych i samorządowych - rys. 10, 11 i 12. 
Rysunek 10. Zadłużenie korporacji finansowych z tytułu emisji dłużnych papierów wartościowych we Francji (w bln USD), 2020

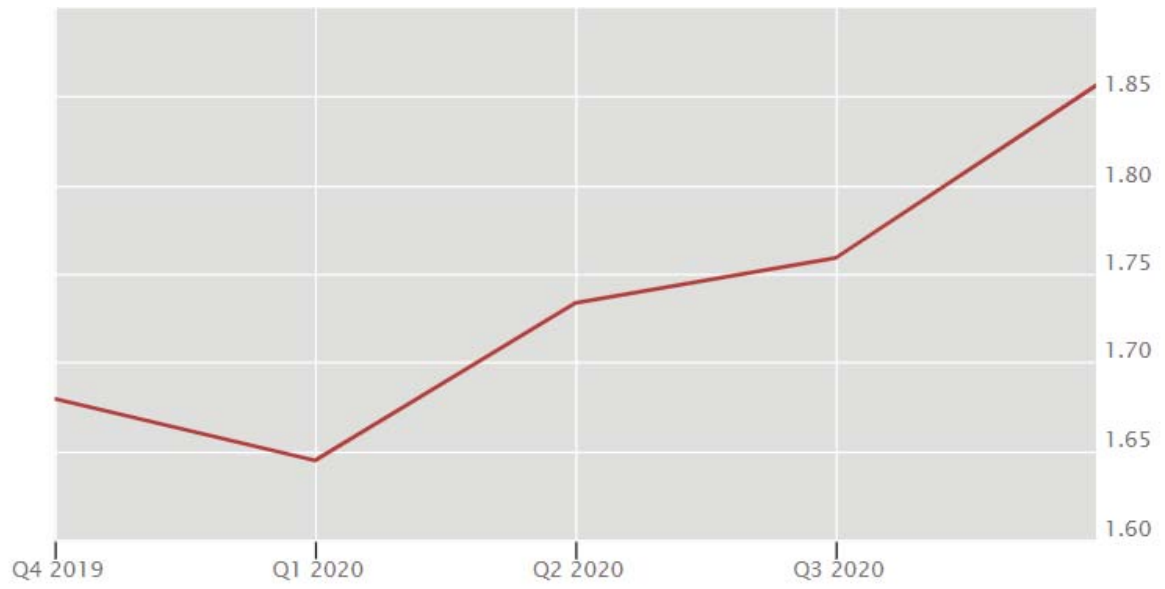

Źródło: Bank for International Settlements (BIS), Debt Securities Statistics, www.bis.org/statistics (data dostępu: 27.10.2021).

Rysunek 11. Zadłużenie korporacji niefinansowych tytułu emisji dłużnych papierów wartościowych we Francji (w mld USD), 2020

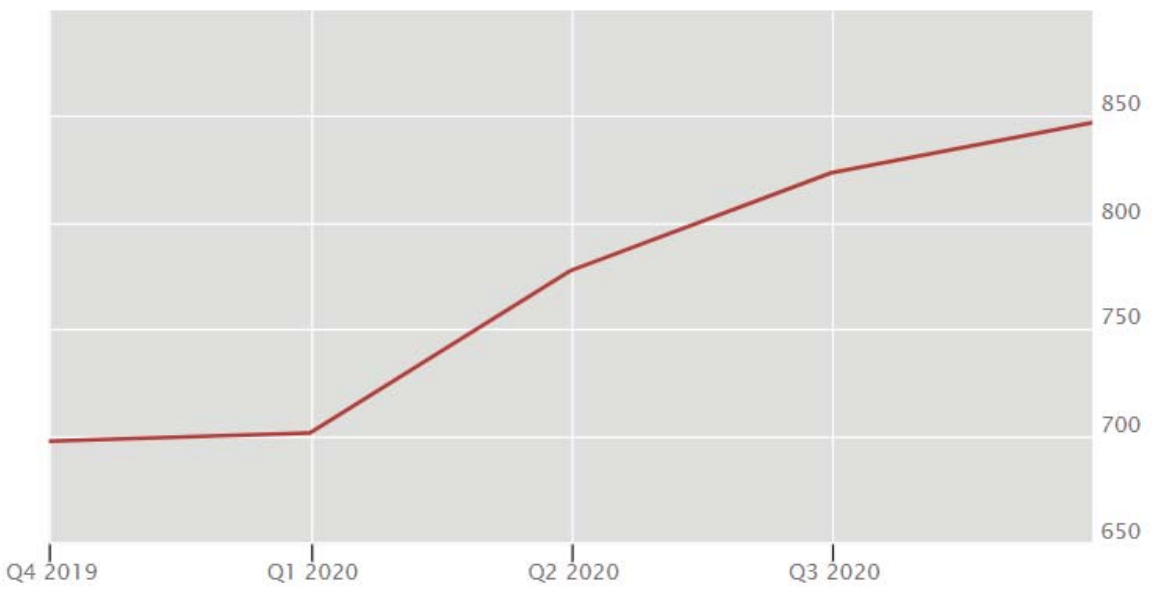

Źródło: Bank for International Settlements (BIS), Debt Securities Statistics, www.bis.org/statistics (data dostępu: 27.10.2021). 
Rysunek 12. Zadłużenie instytucji rządowych i samorządowych z tytułu emisji dłużnych papierów wartościowych we Francji (w mld USD), 2020

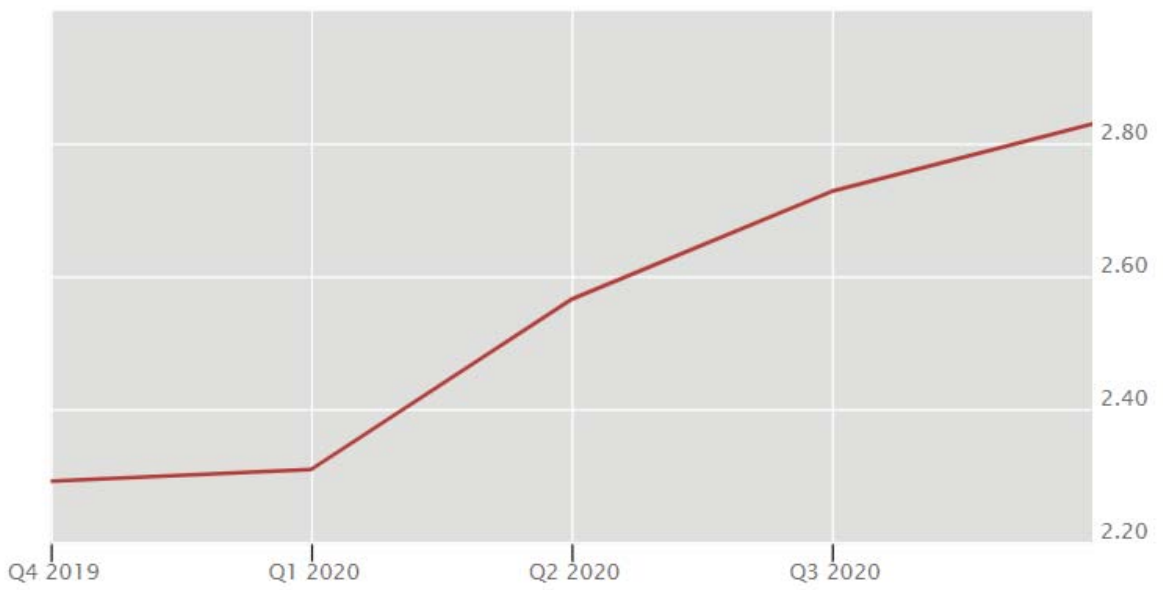

Źródło: Bank for International Settlements (BIS), Debt Securities Statistics, www.bis.org/statistics (data dostępu: 27.10.2021).

Przed wybuchem pandemii COVID-19 trend wzrostowy nie był tak wyraźny, jak po wybuchu. W trzecim kwartale 2019 r. ogólne zadłużenie z tytułu wyemitowanych papierów dłużnych spadło w stosunku do drugiego kwartału 2019 r., co było wynikiem zmniejszenia emisji papierów dłużnych zarówno przez korporacje, jak też instytucje rządowe i samorządowe.

Rynek papierów dłużnych we Francji, podobnie jak rynek hiszpański, rozwija się od początku lat 90 . XX w. Obecnie jest to najlepiej rozwinięty rynek papierów dłużnych w Europie. Wskaźnik zadłużenia z tytułu emisji dłużnych papierów wartościowych do PKB osiąga wartość 2,1 (porównywalny wskaźnik w USA wynosi 2,26). Intensywny wzrost rynku przypada na okres od $2001 \mathrm{r}$. do połowy 2014 r., kolejne lata przyniosły zaś lekkie spadki. Pandemia Covid-19 wyraźnie pobudziła rozwój tego rynku. W czwartym kwartale 2020 r. zadłużenie z tytułu emisji papierów dłużnych osiągnęło najwyższą z dotychczas obserwowanych wartości, tj. 5,53 bln USD - rys. 13. 
Rysunek 13. Całkowite zadłużenie z tytułu emisji dłużnych papierów wartościowych we Francji (w bln USD), 1990-2020

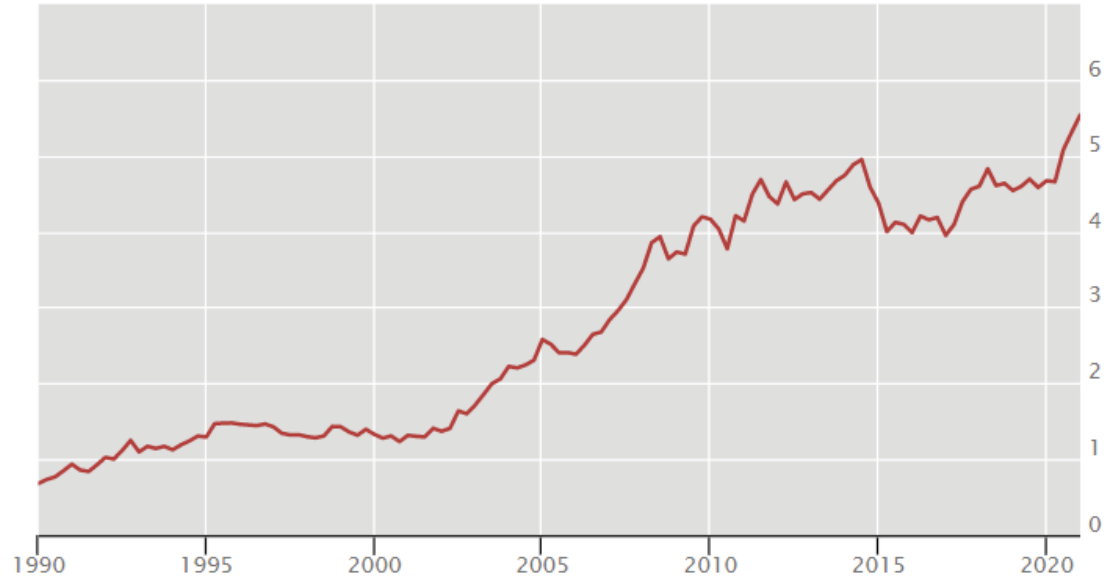

Źródło: Bank for International Settlements (BIS), Debt Securities Statistics, www.bis.org/statistics (data dostępu: 27.10.2021).

\section{Wpływ pandemii COVID-19 na rynki dłużnych papierów wartościowych we Włoszech}

Zadłużenie z tytułu emisji dłużnych papierów wartościowych we Włoszech na koniec 2020 r. wyniosło 3650,0 mld USD. Było wyższe od zadłużenia zarejestrowanego po pierwszym kwartale 2020 r. o 550,2 mld USD - tab. 4.

Tabela 4. Zadłużenie z tytułu emisji dłużnych papierów wartościowych we Włoszech (w mld USD), 2019-2020

\begin{tabular}{|l|c|c|c|c|c|c|c|c|}
\cline { 2 - 9 } \multicolumn{1}{c|}{} & Q1 19 & Q2 19 & Q3 19 & Q4 19 & Q1 20 & Q2 20 & Q3 20 & Q4 20 \\
\hline $\begin{array}{l}\text { Zadłużenie korporacji } \\
\text { finansowych }\end{array}$ & 749,8 & 758,4 & 731,3 & 783,0 & 737,8 & 766,7 & 797,3 & 834,9 \\
\hline $\begin{array}{l}\text { Zadłużenie korporacji } \\
\text { niefinansowych }\end{array}$ & 157,5 & 162,5 & 150,7 & 155,9 & 148,2 & 152,1 & 161,0 & 178,6 \\
\hline $\begin{array}{l}\text { Zadłużenie instytucji } \\
\text { rządowych i samo- } \\
\text { rządowych }\end{array}$ & 2246,9 & 2305,7 & 2198,8 & 2254,9 & 2213,8 & 2377,0 & 2549,8 & 2635,6 \\
\hline Zadłużenie - ogółem & 3154,2 & 3226,5 & 3080,7 & 3193,7 & 3099,8 & 3295,8 & 3508,1 & 3650,0 \\
\hline
\end{tabular}

Źródło: Bank for International Settlements (BIS), Debt Securities Statistics, www.bis.org/statistics (data dostępu: 27.10.2021).

Można było zatem obserwować trend wzrostowy w zakresie wysokości całkowitego zadłużenia z tytułu wyemitowanych papierów dłużnych - rys. 14. 
Rysunek 14. Całkowite zadłużenie z tytułu emisji dłużnych papierów wartościowych we Włoszech (w bln USD), $2020 \mathrm{r}$.

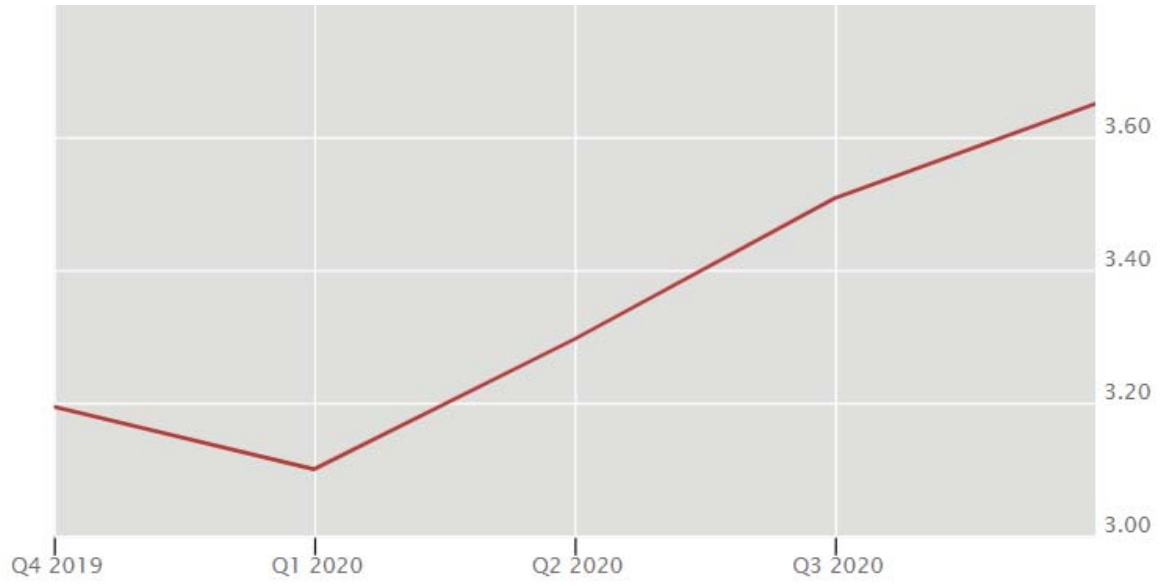

Źródło: Bank for International Settlements (BIS), Debt Securities Statistics, www.bis.org/statistics (data dostępu: 27.10.2021).

Wzrost zadłużenia dotyczył zarówno korporacji finansowych i niefinansowych, jak też instytucji rządowych i samorządowych - rys. 15, 16 i 17.

Rysunek 15. Zadłużenie korporacji finansowych z tytułu emisji dłużnych papierów wartościowych we Włoszech (w mld USD), 2020 r.

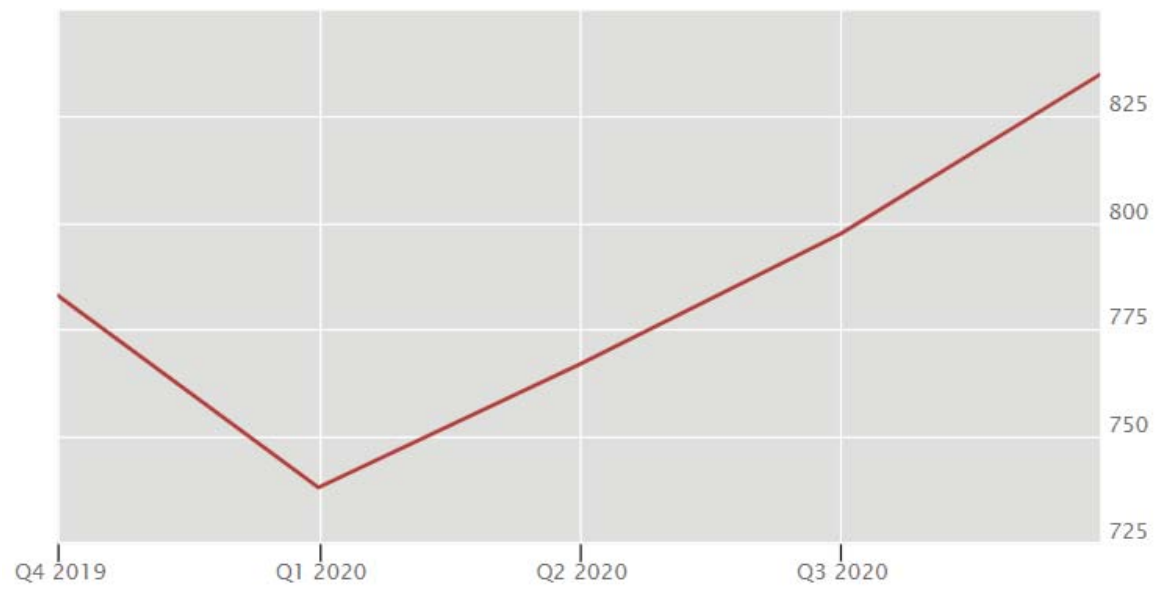

Źródło: Bank for International Settlements (BIS), Debt Securities Statistics, www.bis.org/statistics (data dostępu: 27.10.2021). 
Rysunek 16. Zadłużenie korporacji niefinansowych z tytułu emisji dłużnych papierów wartościowych we Włoszech (w mld USD), $2020 \mathrm{r}$.



Źródło: Bank for International Settlements (BIS), Debt Securities Statistics, www.bis.org/statistics (data dostępu: 27.10.2021).

Rysunek 17. Zadłużenie instytucji rządowych i samorządowych z tytułu emisji dłużnych papierów wartościowych we Włoszech (w mld USD), $2020 \mathrm{r}$.

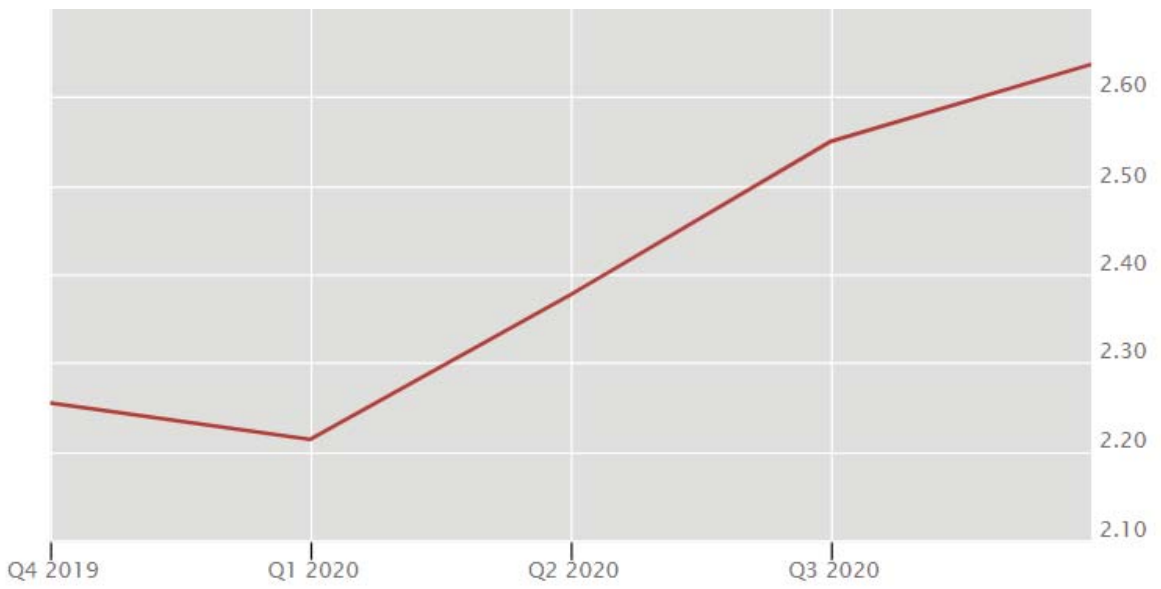

Źródło: Bank for International Settlements (BIS), Debt Securities Statistics, www.bis.org/statistics (data dostępu: 27.10.2021).

Włochy, podobnie jak Francja i Hiszpania, odnotowywały okresy spadków na rynku dłużnych papierów wartościowych przed wybuchem pandemii. W trzecim kwartale 2019 r. ogólne zadłużenie z tytułu wyemitowanych papierów dłużnych spadło w stosunku do drugiego kwartału 2019 r. W okresie tym odnotowano zmniejszenie emisji papierów dłużnych przez korporacje, a także instytucje rządowe i samorządowe. 
Rynek papierów dłużnych we Włoszech zaczął się rozwijać na początku lat 90. XX w. Wskaźnik zadłużenia z tytułu emisji dłużnych papierów wartościowych do PKB osiąga wartość 1,9, co pozwala zaliczyć włoski rynek papierów dłużnych do rynków dobrze rozwiniętych. Intensywny wzrost rynku miał miejsce w latach 2001-2013. Najwyższą wartość zadłużenia odnotowano w trzecim kwartale 2013 r. w wysokości 4,08 bln USD. Wyraźne zmniejszenie emisji dłużnych papierów wartościowych odnotowano w roku 2014. W kolejnych kwartałach wysokość zadłużenia nie przekraczała 3,4 bln USD. Sytuacja zmieniła się w roku 2020, kiedy to wielkość zadłużenia zaczęła rosnąć, osiągając na koniec 2020 r. wartość 3,65 bln USD - rys. 18 .

Rysunek 18. Całkowite zadłużenie z tytułu emisji dłużnych papierów wartościowych we Włoszech (w bln USD), 1990-2020

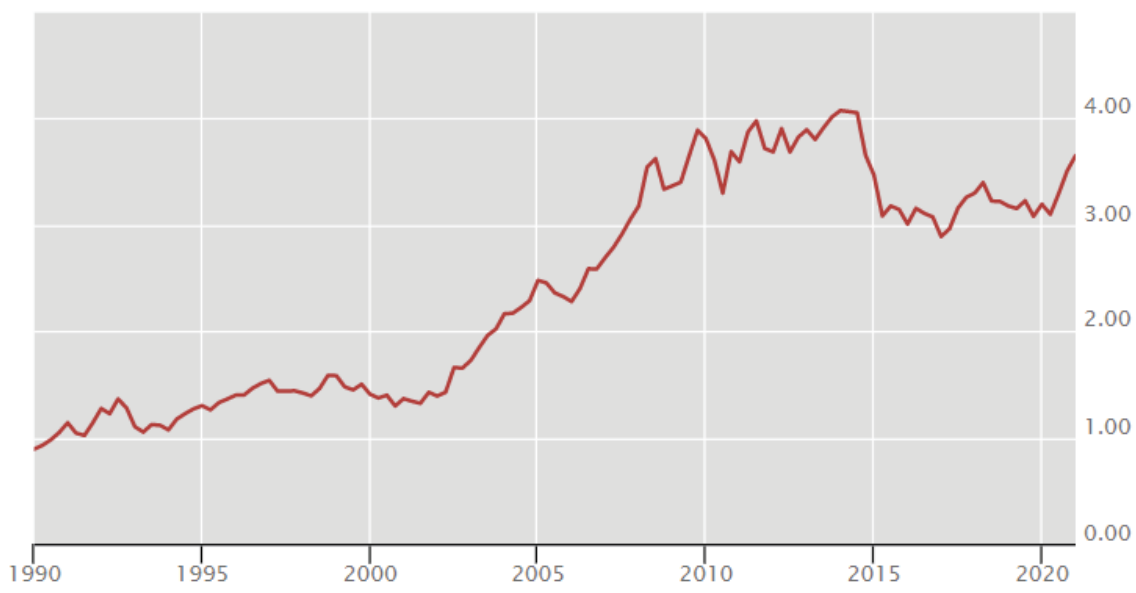

Źródło: Bank for International Settlements (BIS), Debt Securities Statistics, www.bis.org/statistics (data dostępu: 27.10.2021).

\section{Wpływ pandemii COVID-19 na rynki dłużnych papierów wartościowych w Czechach}

Na koniec 2020 r. zadłużenie z tytułu emisji dłużnych papierów wartościowych w Czechach wynosiło 245,9 mld USD, co stanowiło wzrost o 38,1 mld USD w stosunku do pierwszego kwartału 2020 r. - tab. 5. 
Tabela 5. Zadłużenie z tytułu emisji dłużnych papierów wartościowych w Czechach (w mld USD), 2019-2020

\begin{tabular}{|l|c|c|c|c|c|c|c|c|}
\cline { 2 - 9 } \multicolumn{1}{c|}{} & Q1 19 & Q2 19 & Q3 19 & Q4 19 & Q1 20 & Q2 20 & Q3 20 & Q4 20 \\
\hline $\begin{array}{l}\text { Zadłużenie korporacji } \\
\text { finansowych }\end{array}$ & 134,4 & 137,1 & 133,6 & 122,7 & 125,2 & 121,2 & 127,7 & 134,9 \\
\hline $\begin{array}{l}\text { Zadłużenie korporacji } \\
\text { niefinansowych }\end{array}$ & 16,1 & 16,5 & 15,6 & 16,3 & 14,0 & 14,6 & 15,0 & 16,3 \\
\hline $\begin{array}{l}\text { Zadłużenie instytucji } \\
\text { rządowych i samo- } \\
\text { rządowych (general } \\
\text { government) }\end{array}$ & 72,6 & 74,3 & 69,2 & 70,8 & 68,6 & 88,1 & 88,1 & 94,7 \\
\hline Zadłużenie - ogółem & 223,1 & 227,9 & 218,5 & 209,9 & 207,8 & 223,9 & 230,9 & 245,9 \\
\hline
\end{tabular}

Źródło: Bank for International Settlements (BIS), Debt Securities Statistics, www.bis.org/statistics (data dostępu: 27.10.2021).

Czechy, podobnie jak pozostałe omawiane kraje, odnotowały trend wzrostowy w zakresie wysokości całkowitego zadłużenia z tytułu wyemitowanych papierów dłużnych - rys. 19.

Rysunek 19. Zadłużenie z tytułu emisji dłużnych papierów wartościowych w Czechach (w mld USD), $2020 \mathrm{r}$.

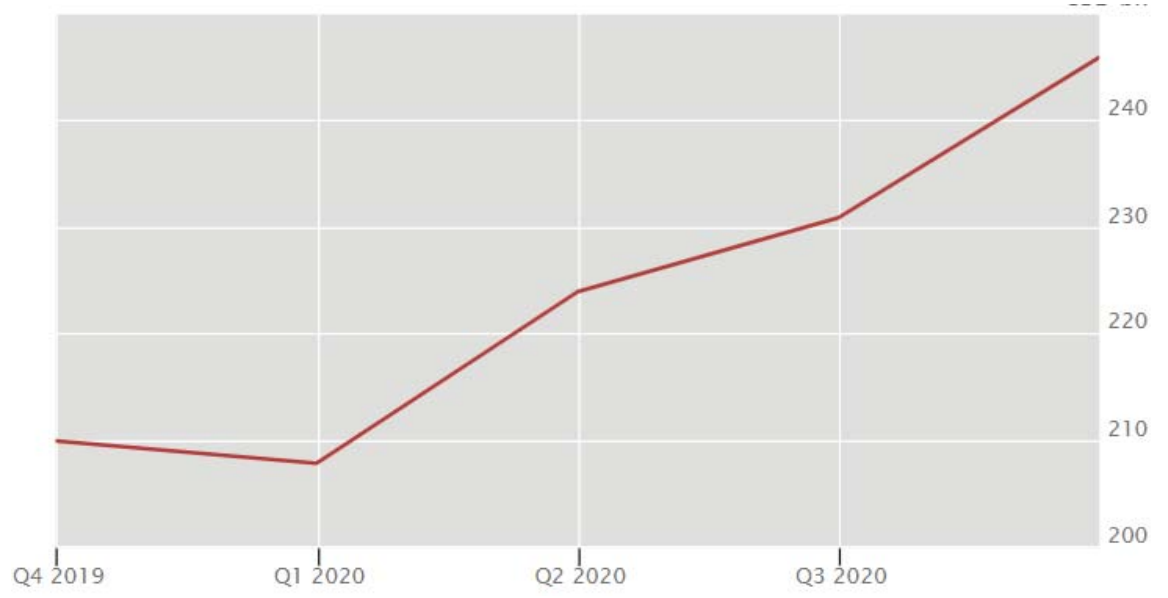

Źródło: Bank for International Settlements (BIS), Debt Securities Statistics, www.bis.org/statistics (data dostępu: 27.10.2021).

Wzrost zadłużenia dotyczył zarówno korporacji finansowych i niefinansowych, jak też instytucji rządowych i samorządowych - rys. 20, 21 i 22. 
Rysunek 20. Zadłużenie korporacji finansowych tytułu emisji dłużnych papierów wartościowych w Czechach (w mld USD), $2020 \mathrm{r}$.

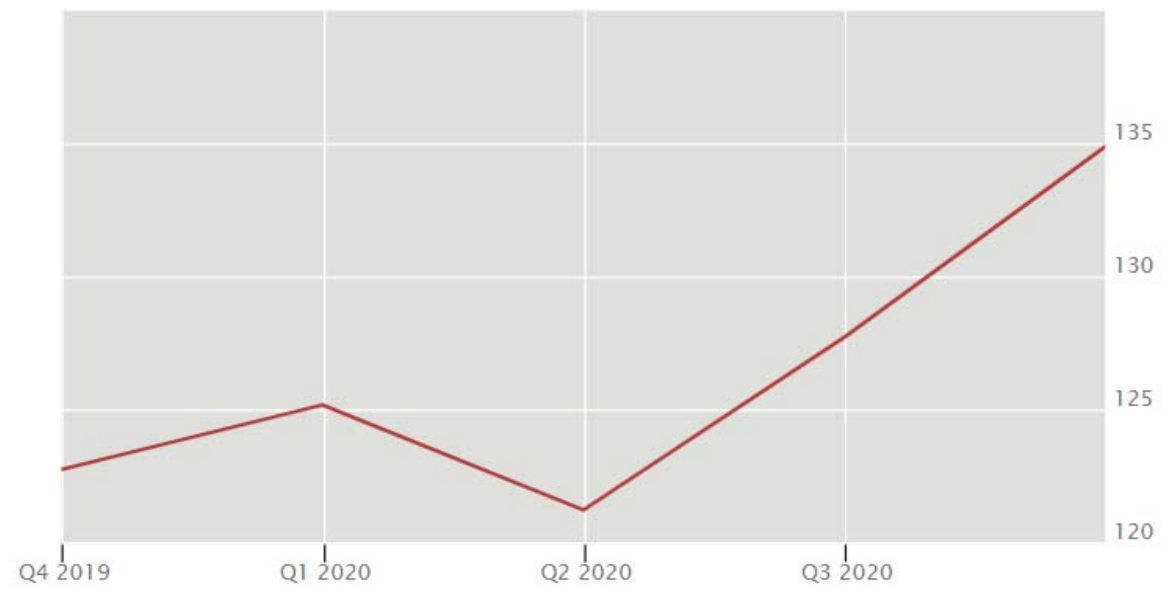

Źródło: Bank for International Settlements (BIS), Debt Securities Statistics, www.bis.org/statistics (data dostępu: 27.10.2021).

Rysunek 21. Zadłużenie korporacji niefinansowych tytułu emisji dłużnych papierów wartościowych w Czechach (w mld USD), $2020 \mathrm{r}$.



Źródło: Bank for International Settlements (BIS), Debt Securities Statistics, www.bis.org/statistics (data dostępu: 27.10.2021). 
Rysunek 22. Zadłużenie instytucji rządowych i samorządowych z tytułu emisji dłużnych papierów wartościowych w Czechach (w mld USD), $2020 \mathrm{r}$.

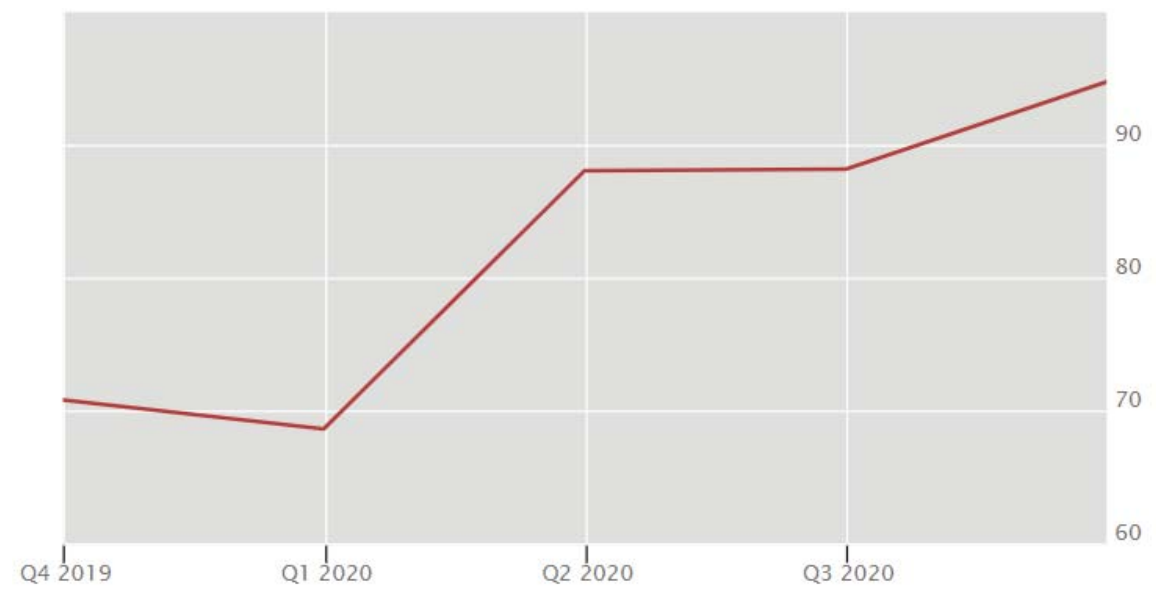

Źródło: Bank for International Settlements (BIS), Debt Securities Statistics, www.bis.org/statistics (data dostępu: 27.10.2021).

W roku 2019 można było obserwować w Czechach trend spadkowy w zakresie wysokości zadłużenia z tytułu dłużnych papierów wartościowych. Trend ten trwał do końca pierwszego kwartału 2020 r. Okres pandemii COVID-19 odwrócił istniejący trend. Wielkość zadłużenia korporacji finansowych i niefinansowych zaczęła rosnąć. Również instytucje rządowe i samorządowe zwiększyły ilość kapitałów pozyskiwanych w drodze emisji papierów dłużnych.

Rynek papierów dłużnych w Czechach należy do rynków słabo rozwiniętych. Wskaźnik zadłużenia z tytułu emisji dłużnych papierów wartościowych do PKB wynosi zaledwie 1. Początki rozwoju tego rynku przypadają na lata 2005-2006. Szczególnie dynamiczny wzrost rynku miał miejsce w roku 2017 - rys. 23. 
Rysunek 23. Całkowite zadłużenie z tytułu emisji dłużnych papierów wartościowych w Czechach (w mld USD), 2008-2020

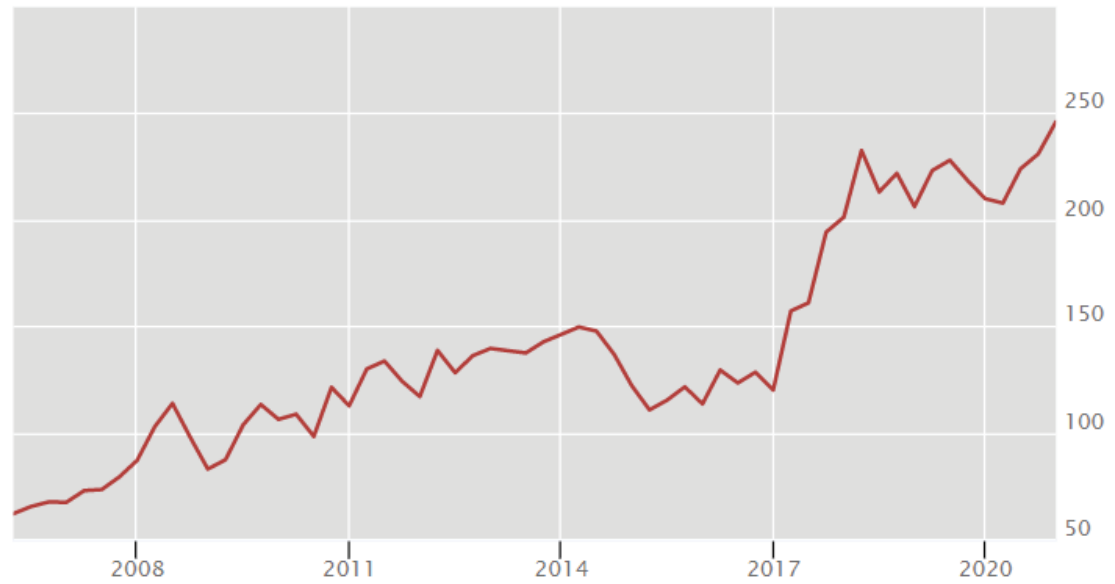

Źródło: Bank for International Settlements (BIS), Debt Securities Statistics, www.bis.org/statistics (data dostępu: 27.10.2021).

\section{Wpływ pandemii COVID-19 na rynki dłużnych papierów wartościowych na Słowacji}

W okresie pandemii COVID-19 (od końca pierwszego kwartału 2020 r. do końca 2020 r.) Słowacja odnotowała wzrost zadłużenia z tytułu emisji dłużnych papierów wartościowych na poziomie 16,7 mld USD. Zadłużenie na koniec $2020 \mathrm{r}$. wynosiło 75,1 mld USD - tab. 6.

Tabela 6. Zadłużenie z tytułu emisji dłużnych papierów wartościowych na Słowacji (w mld USD), 2019-2020

\begin{tabular}{|l|c|c|c|c|c|c|c|c|}
\cline { 2 - 9 } \multicolumn{1}{c|}{} & Q1 19 & Q2 19 & Q3 19 & Q4 19 & Q1 20 & Q2 20 & Q3 20 & Q4 20 \\
\hline $\begin{array}{l}\text { Zadłużenie korpora- } \\
\text { cji finansowych }\end{array}$ & 10,7 & 11,8 & 11,6 & 12,6 & 11,1 & 11,8 & 12,3 & 12,8 \\
\hline $\begin{array}{l}\text { Zadłużenie korpora- } \\
\text { cji niefinansowych }\end{array}$ & 4,2 & 4,3 & 4,1 & 4,2 & 4,1 & 4,6 & 4,8 & 5,0 \\
\hline $\begin{array}{l}\text { Zadłużenie instytucji } \\
\text { rządowych i samo- } \\
\text { rządowych }\end{array}$ & 43,2 & 43,4 & 41,8 & 43,0 & 43,2 & 52,5 & 55,0 & 57,3 \\
\hline Zadłużenie- ogółem & 58,1 & 59,5 & 57,5 & 59,9 & 58,4 & 68,9 & 72,0 & 75,1 \\
\hline
\end{tabular}

Źródło: Bank for International Settlements (BIS), Debt Securities Statistics, www.bis.org/statistics (data dostępu: 27.10.2021).

Można było zatem obserwować trend wzrostowy w zakresie wysokości całkowitego zadłużenia z tytułu wyemitowanych papierów dłużnych - rys. 24. 
Rysunek 24. Całkowite zadłużenie z tytułu emisji dłużnych papierów wartościowych na Słowacji (w mld USD), $2020 \mathrm{r}$.

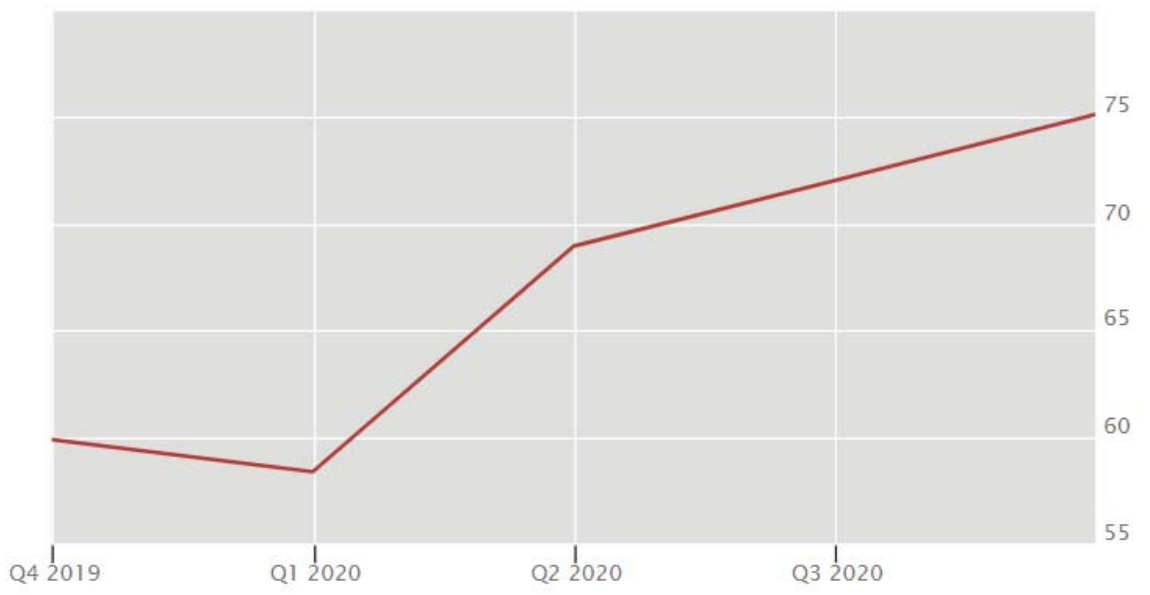

Źródło: Bank for International Settlements (BIS), Debt Securities Statistics, www.bis.org/statistics (data dostępu: 27.10.2021).

Wzrost zadłużenia dotyczył zarówno korporacji finansowych i niefinansowych, jak też instytucji rządowych i samorządowych - rys. 25, 26 i 27.

Rysunek 25. Zadłużenie korporacji finansowych z tytułu emisji dłużnych papierów wartościowych na Słowacji (w mld USD), $2020 \mathrm{r}$.

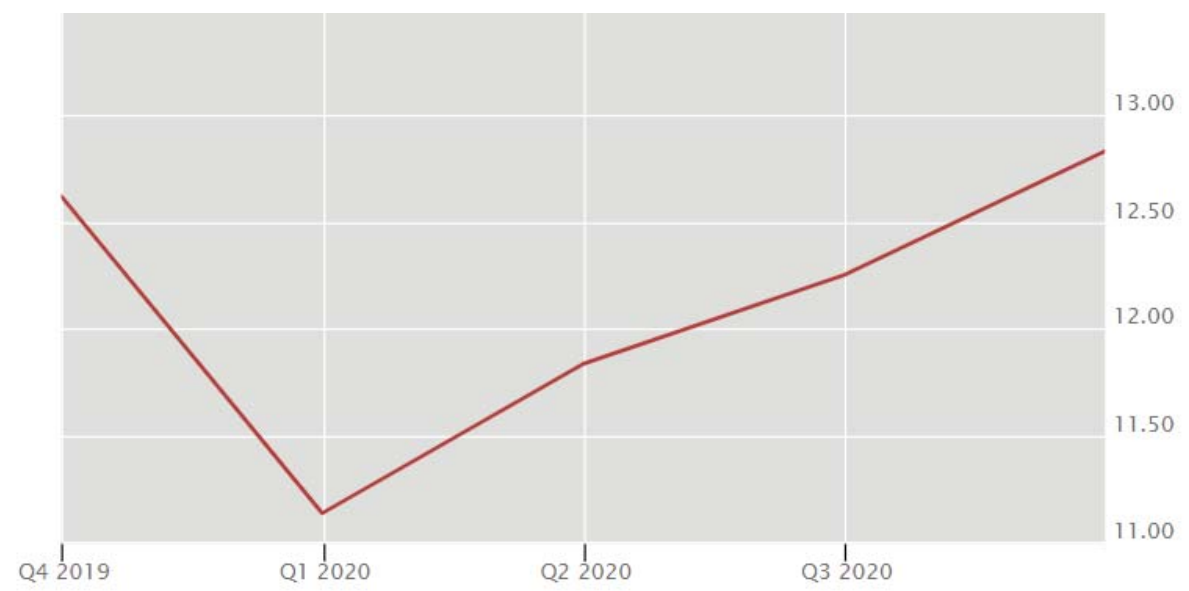

Źródło: Bank for International Settlements (BIS), Debt Securities Statistics, www.bis.org/statistics (data dostępu: 27.10.2021). 
Rysunek 26. Zadłużenie korporacji niefinansowych z tytułu emisji dłużnych papierów wartościowych na Słowacji (w mld USD), $2020 \mathrm{r}$.

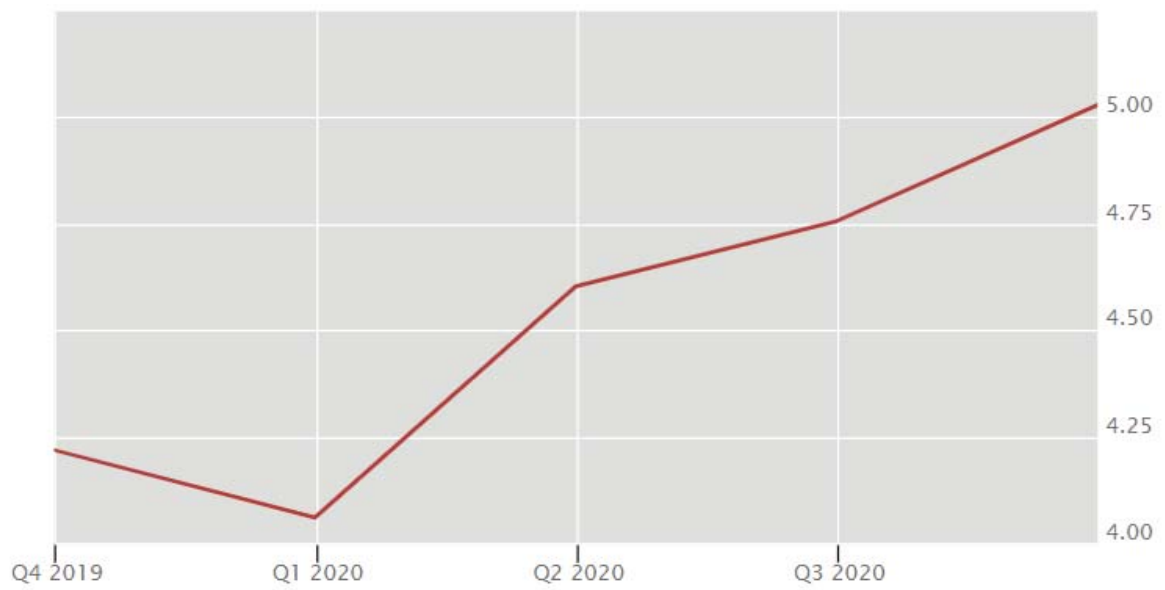

Źródło: Bank for International Settlements (BIS), Debt Securities Statistics, www.bis.org/statistics (data dostępu: 27.10.2021).

Rysunek 27. Zadłużenie instytucji rządowych i samorządowych z tytułu emisji dłużnych papierów wartościowych na Słowacji (w mld USD), 2020 r.

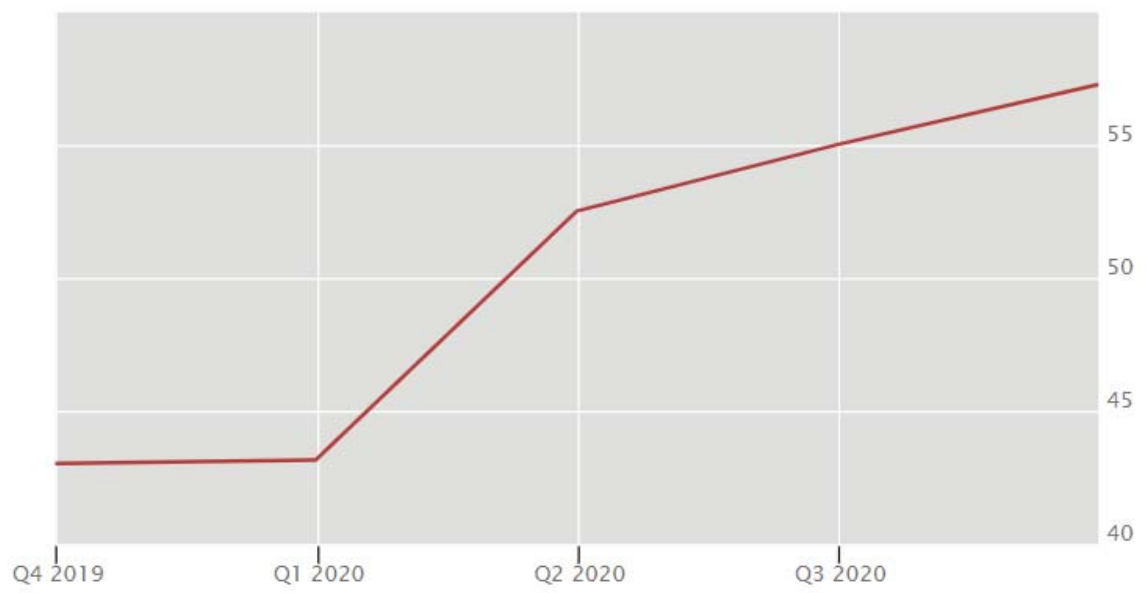

Źródło: Bank for International Settlements (BIS), Debt Securities Statistics, www.bis.org/statistics (data dostępu: 27.10.2021).

Okres przed wybuchem pandemii COVID-19 na Słowacji (rok 2019) to czas zarówno wzrostów, jak i spadków w zakresie zadłużenia z tytułu papierów dłużnych. W trzecim kwartale 2019 r. ogólne zadłużenie z tytułu wyemitowanych papierów dłużnych spadło w stosunku do drugiego kwartału 2019 r. Podobny spadek można było zaobserwować w pierwszym kwartale 2020 r. w stosunku do 
czwartego kwartału 2019 r. W okresie pandemii COVID-19 (rok 2020), Słowacja zaczęła odnotowywać wzrosty w zakresie emisji papierów dłużnych. Rozmiary emisji osiągnęły wartości dotychczas nienotowane.

Słowacki rynek papierów dłużnych, podobnie jak rynek czeski, jest rynkiem słabo rozwiniętym. Wskaźnik zadłużenia z tytułu emisji dłużnych papierów wartościowych do PKB wynosi zaledwie 0,7 . Początki rozwoju tego rynku przypadają na lata 1993-1994. Wyraźny trend wzrostowy w zakresie wielkości zadłużenia można było obserwować do końca roku 2013. Rok 2014 przyniósł spadki, które jednak zostały szybko zażegnane - rys. 28.

Rysunek 28. Całkowite zadłużenie z tytułu emisji dłużnych papierów wartościowych na Słowacji (w mld USD), 1995-2020

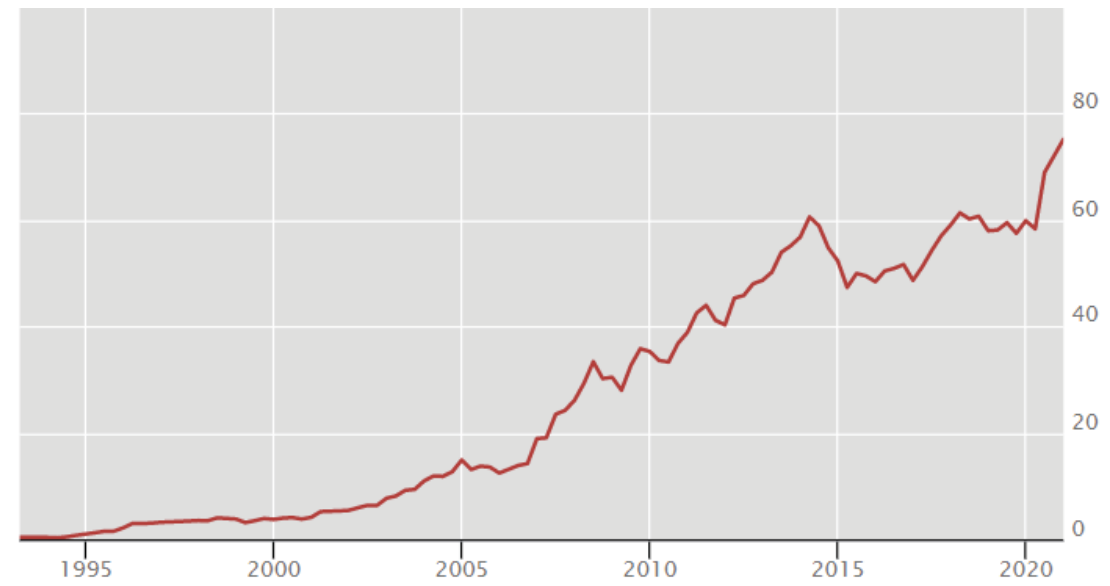

Źródło: Bank for International Settlements (BIS), Debt Securities Statistics, www.bis.org/statistics (data dostępu: 27.10.2021).

\section{Wpływ pandemii COVID-19 na rynki dłużnych papierów wartościowych na Węgrzech}

Zadłużenie z tytułu emisji dłużnych papierów wartościowych na Węgrzech na koniec 2020 r. wyniosło 138,2 mld USD, co oznacza, że Węgry odnotowały wzrost zadłużenia w stosunku do pierwszego kwartału 2020 r. o 34,3 mld USD - tab. 7. 
Tabela 7. Zadłużenie z tytułu emisji dłużnych papierów wartościowych na Węgrzech (w mld USD), 2019-2020

\begin{tabular}{|l|r|r|r|r|r|r|r|r|}
\cline { 2 - 9 } \multicolumn{1}{c|}{} & Q1 19 & Q2 19 & Q3 19 & Q4 19 & Q1 20 & Q2 20 & Q3 20 & Q4 20 \\
\hline $\begin{array}{l}\text { Zadłużenie korporacji } \\
\text { finansowych }\end{array}$ & 8,3 & 8,5 & 8,8 & 9,6 & 8,8 & 9,7 & 10,2 & 11,2 \\
\hline $\begin{array}{l}\text { Zadłużenie korporacji } \\
\text { niefinansowych }\end{array}$ & 2,2 & 2,1 & 1,6 & 2,5 & 2,5 & 2,8 & 3,5 & 5,1 \\
\hline $\begin{array}{l}\text { Zadłużenie instytucji } \\
\text { rządowych i samo- } \\
\text { rządowych }\end{array}$ & 103,1 & 104,6 & 100,5 & 103,3 & 92,6 & 100,9 & 107,6 & 121,9 \\
\hline Zadłużenie - ogółem & 113,6 & 115,2 & 110,9 & 115,5 & 103,9 & 113,4 & 121,3 & 138,2 \\
\hline
\end{tabular}

Źródło: Bank for International Settlements (BIS), Debt Securities Statistics, www.bis.org/statistics (data dostępu: 27.10.2021).

W okresie pandemii COVID-19, w roku 2020, Węgry odnotowały trend wzrostowy w zakresie wysokości całkowitego zadłużenia z tytułu wyemitowanych papierów dłużnych - rys. 29.

Rysunek 29. Całkowite zadłużenie z tytułu emisji dłużnych papierów wartościowych na Węgrzech (w mld USD), $2020 \mathrm{r}$.

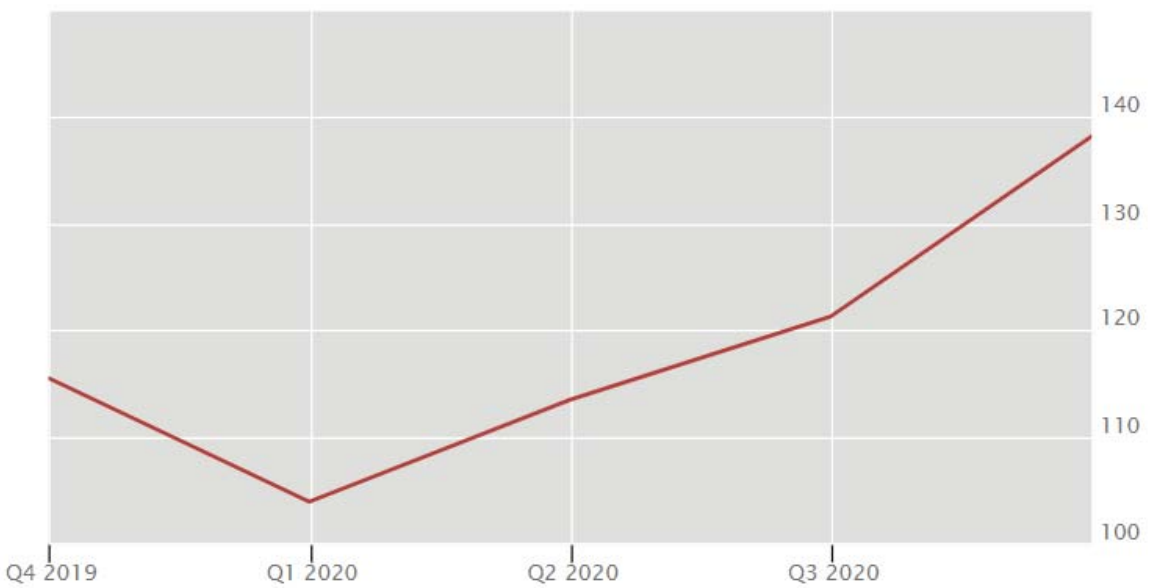

Źródło: Bank for International Settlements (BIS), Debt Securities Statistics, www.bis.org/statistics (data dostępu: 27.10.2021).

Wzrost zadłużenia dotyczył zarówno korporacji finansowych i niefinansowych, jak też instytucji rządowych i samorządowych - rys. 30, 31 i 32. 
Rysunek 30. Zadłużenie korporacji finansowych z tytułu emisji dłużnych papierów wartościowych na Węgrzech (w mld USD), $2020 \mathrm{r}$.

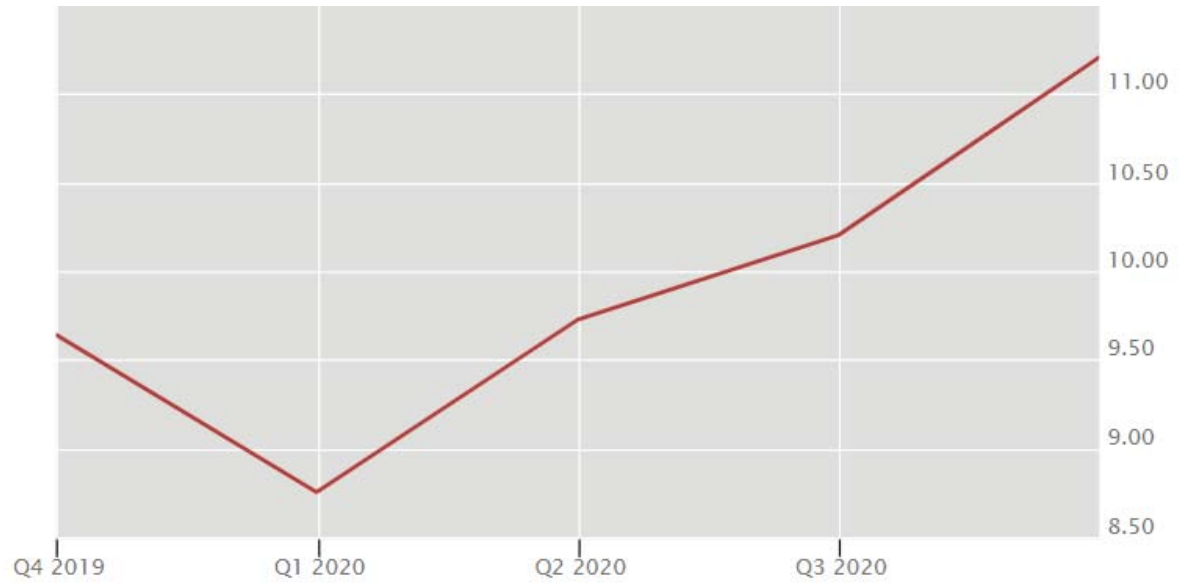

Źródło: Bank for International Settlements (BIS), Debt Securities Statistics, www.bis.org/statistics (data dostępu: 27.10.2021).

Rysunek 31. Zadłużenie korporacji niefinansowych z tytułu emisji dłużnych papierów wartościowych na Węgrzech (w mld USD), $2020 \mathrm{r}$.

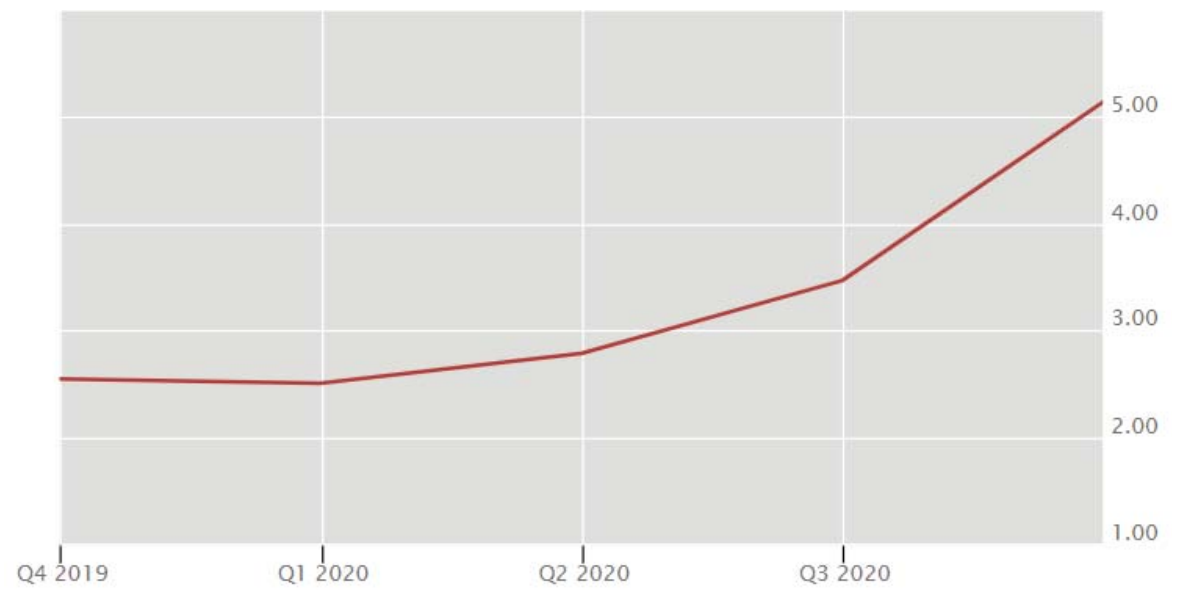

Źródło: Bank for International Settlements (BIS), Debt Securities Statistics, www.bis.org/statistics (data dostępu: 27.10.2021). 
Rysunek 32. Zadłużenie instytucji rządowych i samorządowych z tytułu emisji dłużnych papierów wartościowych na Węgrzech (w mld USD), $2020 \mathrm{r}$.

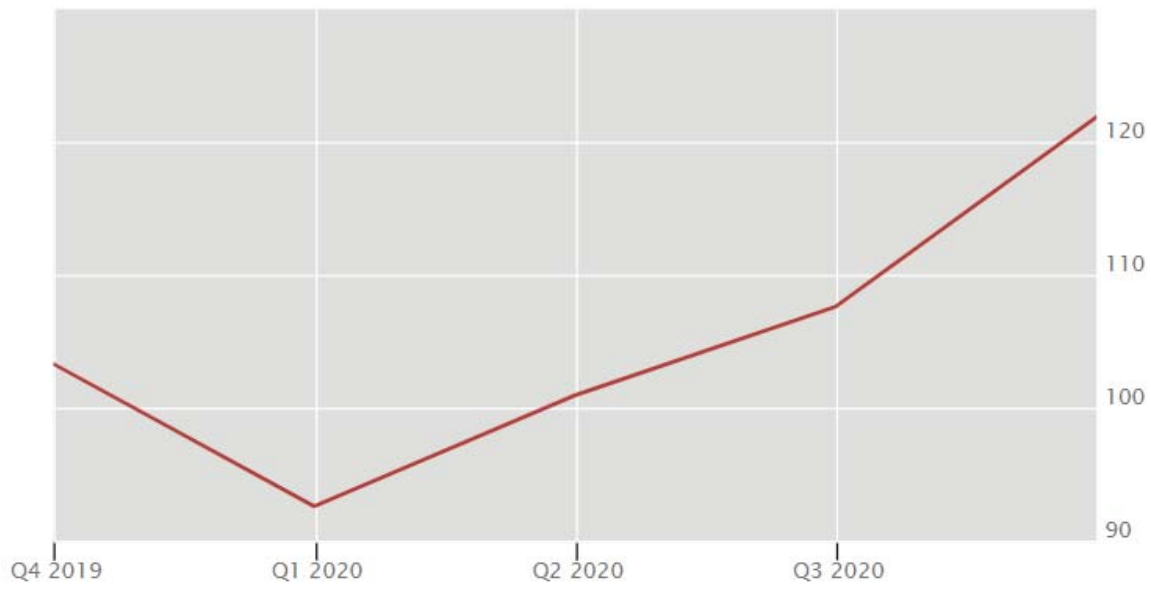

Źródło: Bank for International Settlements (BIS), Debt Securities Statistics, www.bis.org/statistics (data dostępu: 27.10.2021).

Z danych kwartalnych obejmujących rynek dłużnych papierów wartościowych na Węgrzech wynika, że przed wybuchem pandemii COVID-19, w trzecim kwartale 2019 r., ogólne zadłużenie z tytułu wyemitowanych papierów dłużnych na Węgrzech spadło w stosunku do drugiego kwartału 2019 r. (do czego przyczyniło się zmniejszenie emisji papierów dłużnych przez korporacje niefinansowe, jak też instytucje rządowe i samorządowe). Podobne spadki obserwowano w pierwszym kwartale 2020 r. (w stosunku do czwartego kwartału 2019 r.).

Rynek papierów dłużnych na Węgrzech to rynek bardzo słabo rozwinięty. Wskaźnik zadłużenia z tytułu emisji dłużnych papierów wartościowych do PKB wynosi zaledwie 0,9. Początki rozwoju tego rynku przypadają na lata 1997-1998. Wyraźny trend wzrostowy w zakresie wielkości zadłużenia można było obserwować od 2002 r. do końca drugiego kwartału 2007 r. Późniejszy okres można opisać jako trend boczny - całkowita wysokość zadłużenia wahała się w przedziale od 92 mld USD do 140 mld USD - rys. 33. 
Rysunek 33. Całkowite zadłużenie z tytułu emisji dłużnych papierów wartościowych na Węgrzech (w mld USD), 2000-2020

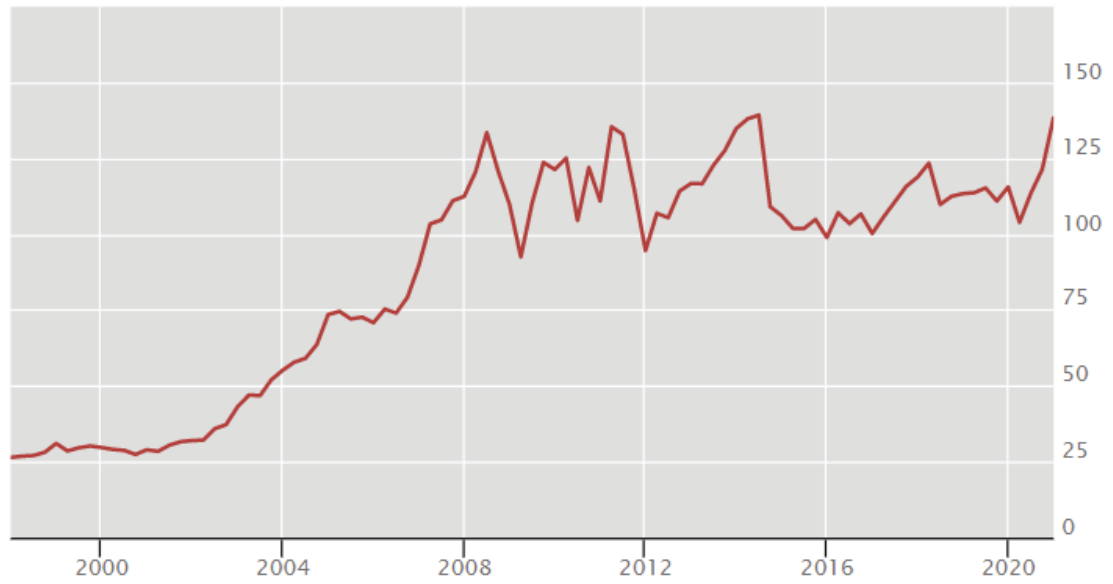

Źródło: Bank for International Settlements (BIS), Debt Securities Statistics, www.bis.org/statistics (data dostępu: 27.10.2021).

\section{Wpływ pandemii COVID-19 na rynki dłużnych papierów wartościowych w Polsce}

W okresie pandemii COVID-19 (od końca pierwszego kwartału 2020 r. do końca 2020 r.), Polska zarejestrowała wzrost zadłużenia z tytułu emisji dłużnych papierów wartościowych o 116,1 mld USD. Zadłużenie na koniec 2020 r. wynosiło 408,4 mld USD - tab. 8.

Tabela 8. Zadłużenie z tytułu emisji dłużnych papierów wartościowych w Polsce (w mld USD), 2019-2020

\begin{tabular}{|l|c|c|c|c|c|c|c|c|}
\cline { 2 - 9 } \multicolumn{1}{c|}{} & Q1 19 & Q2 19 & Q3 19 & Q4 19 & Q1 20 & Q2 20 & Q3 20 & Q4 20 \\
\hline $\begin{array}{l}\text { Zadłużenie korporacji } \\
\text { finansowych }\end{array}$ & 45,7 & 48,5 & 42,7 & 40,7 & 37,3 & 58,4 & 68,2 & 62,4 \\
\hline $\begin{array}{l}\text { Zadłużenie korporacji } \\
\text { niefinansowych }\end{array}$ & 27,3 & 28,0 & 25,7 & 23,7 & 21,0 & 19,8 & 21,0 & 22,5 \\
\hline $\begin{array}{l}\text { Zadłużenie instytucji } \\
\text { rządowych i samo- } \\
\text { rządowych (general } \\
\text { government) }\end{array}$ & 241,8 & 248,0 & 233,4 & 239,5 & 233,9 & 294,9 & 306,4 & 323,5 \\
\hline Zadłużenie - ogółem & 314,8 & 324,5 & 301,7 & 303,9 & 292,3 & 373,0 & 395,6 & 408,4 \\
\hline
\end{tabular}

Źródło: Bank for International Settlements (BIS), Debt Securities Statistics, www.bis.org/statistics (data dostępu: 27.10.2021). 
Tym samym Polska dołączyła do grona krajów, w których obserwowano trend wzrostowy w zakresie wysokości całkowitego zadłużenia z tytułu wyemitowanych papierów dłużnych w okresie pandemii COVID-19 - rys. 34.

Rysunek 34. Całkowite zadłużenie z tytułu emisji dłużnych papierów wartościowych w Polsce (w mld USD), $2020 \mathrm{r}$.

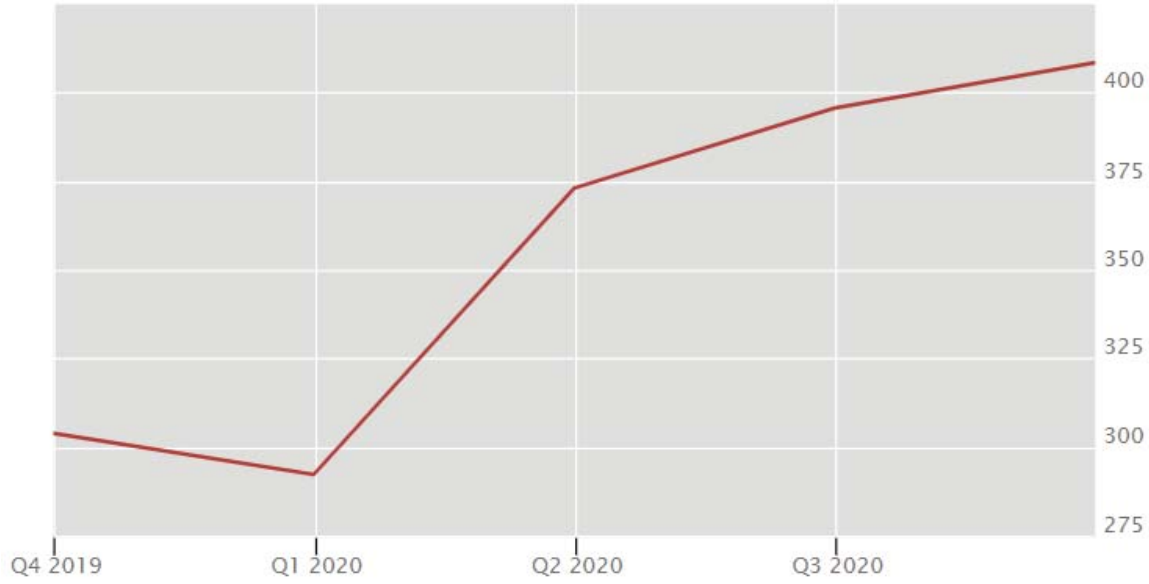

Źródło: Bank for International Settlements (BIS), Debt Securities Statistics, www.bis.org/statistics (data dostępu: 27.10.2021).

Wyraźny wzrost zadłużenia dotyczył jednak tylko instytucji rządowych i samorządowych - rys. 35 .

Rysunek 35. Zadłużenie instytucji rządowych i samorządowych z tytułu emisji dłużnych papierów wartościowych w Polsce (w mld USD), 2020

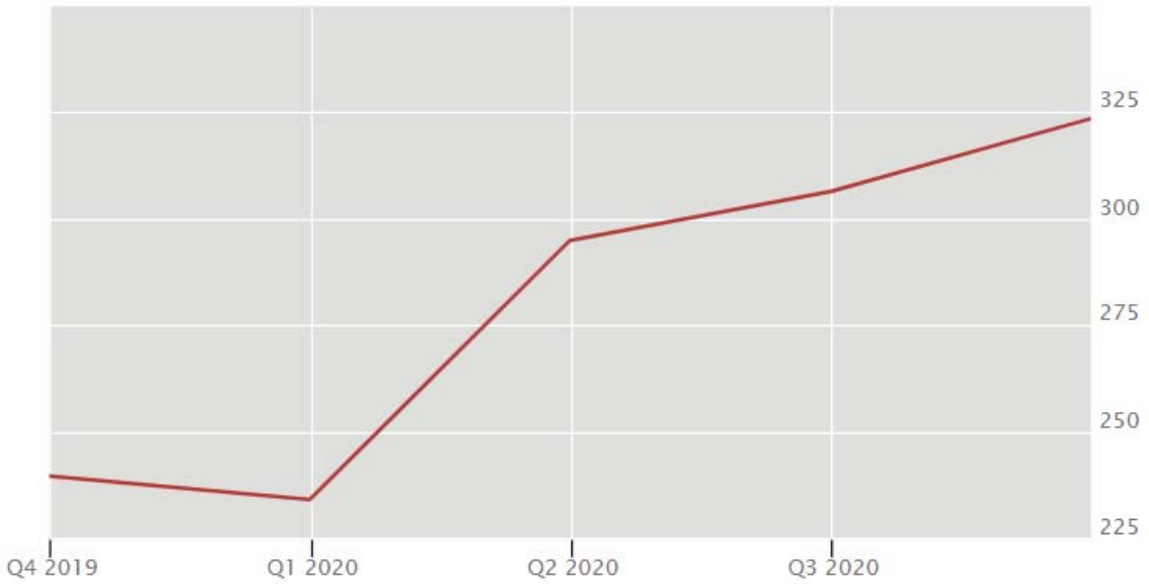

Źródło: Bank for International Settlements (BIS), Debt Securities Statistics, www.bis.org/statistics (data dostępu: 27.10.2021). 
Korporacje niefinansowe $\mathrm{w}$ drugim kwartale 2020 r. odnotowały spadek w stosunku do pierwszego kwartału 2020 r. - rys. 36.

Rysunek 36. Zadłużenie korporacji niefinansowych tytułu emisji dłużnych papierów wartościowych w Polsce (w mld USD), 2020

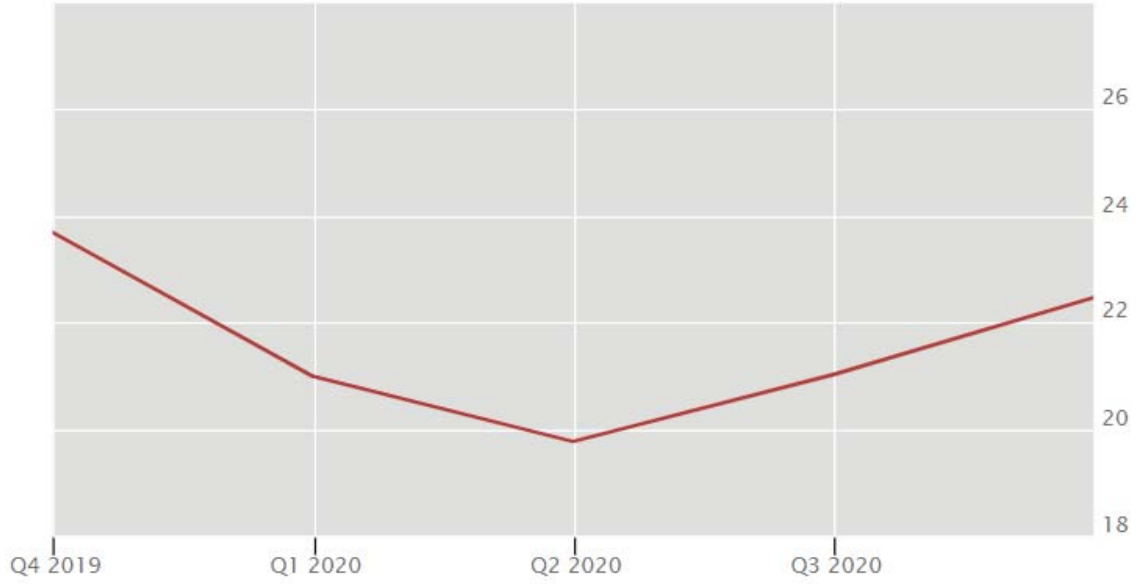

Źródło: Bank for International Settlements (BIS), Debt Securities Statistics, www.bis.org/statistics (data dostępu: 27.10.2021).

Zadłużenie korporacji niefinansowych spadło w czwartym kwartale $2020 \mathrm{r}$. (w stosunku do trzeciego kwartału 2020 r.) - rys. 37.

Rysunek 37. Zadłużenie korporacji finansowych tytułu emisji dłużnych papierów wartościowych w Polsce (w mld USD), 2020

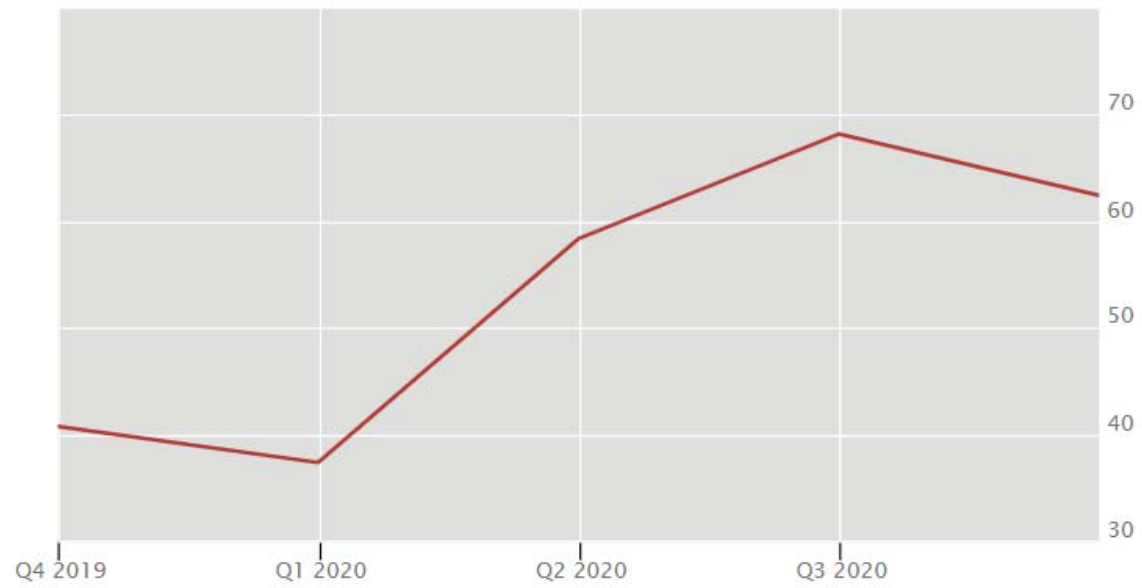

Źródło: Bank for International Settlements (BIS), Debt Securities Statistics, www.bis.org/statistics (data dostępu: 27.10.2021). 
W Polsce, podobnie jak w pozostałych omawianych krajach, sytuacja w zakresie wysokości zadłużenia z tytułu emisji papierów dłużnych przed kryzysem COVID-19 zmieniała się. Obserwowano zarówno wzrosty, jak i spadki tego zadłużenia. W trzecim kwartale 2019 r. ogólne zadłużenie z tytułu wyemitowanych papierów dłużnych spadło w stosunku do drugiego kwartału 2019 r., do czego przyczyniło się zmniejszenie emisji papierów dłużnych zarówno przez korporacje, jak też instytucje rządowe i samorządowe.

Rynek papierów dłużnych w Polsce należy do najsłabiej rozwiniętych rynków w grupie omawianych krajów. Wskaźnik zadłużenia z tytułu emisji dłużnych papierów wartościowych do PKB osiąga wartość zaledwie 0,69 , co oznacza, że papiery dłużne są mało popularną formą pozyskiwania kapitału. Niemal $80 \% \mathrm{dłu}$ gu należy do instytucji rządowych i samorządowych. W latach 2005-2020, rynek dłużnych papierów wartościowych w Polsce odznaczał się niskim tempem rozwoju - rys. 38 .

Rysunek 38. Całkowite zadłużenie z tytułu emisji dłużnych papierów wartościowych w Polsce (w mld USD), 2005-2020

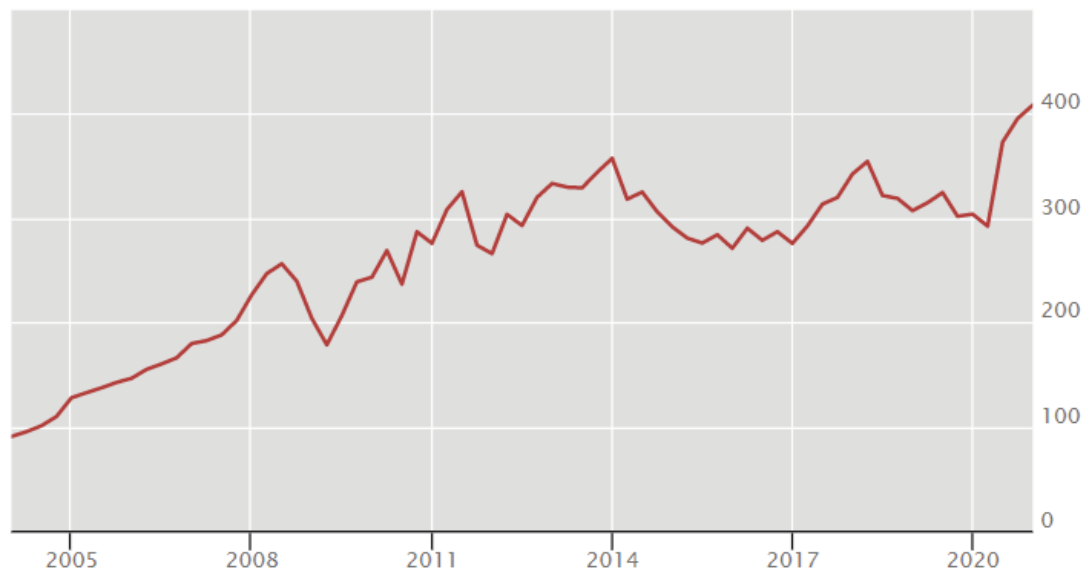

Źródło: Bank for International Settlements (BIS), Debt Securities Statistics, www.bis.org/statistics (data dostępu: 27.10.2021).

\section{Wpływ pandemii COVID-19 na rynki dłużnych papierów wartościowych w omawianych krajach - analiza porównawcza}

Pandemia COVID-19 przyczyniła się do wzrostu zadłużenia z tytułu emisji dłużnych papierów wartościowych we wszystkich omawianych krajach w $2020 \mathrm{r}$. Największy wzrost $\mathrm{w}$ ujęciu wartościowym (przyrost absolutny) nastąpił we Francji (o 877,6 mld USD), na drugim miejscu uplasowały się Włochy (wzrost o 550,2 mld USD), trzecie miejsce zajęła Hiszpania (wzrost o 361,9 mld USD). 
Widać zatem, że porównując przyrost zadłużenia z tytułu papierów dłużnych w roku 2020, w wielkościach bezwzględnych, dominujące miejsce zajmują kraje wysoko rozwinięte - tab. 9.

Porównanie dynamiki zmian w zakresie zadłużenia w roku 2020 dostarcza jednak innych wniosków. Wzrost zadłużenia z tytułu emisji dłużnych papierów wartościowych na Słowacji, na Węgrzech i w Polsce był znacznie bardziej gwałtowny niż w pozostałych krajach. Słowacja odnotowała wzrost na poziomie $28,4 \%$, Węgry - 33\%, a Polska - 39,7\%. W pozostałych omawianych krajach wzrost (odnotowany na koniec czwartego kwartału 2020 r.) nie przekroczył $20 \%$ wartości zadłużenia zarejestrowanego na koniec pierwszego kwartału $2020 \mathrm{r}$. - tab. 9 .

Tabela 9. Zadłużenie ogółem z tytułu emisji dłużnych papierów wartościowych w wybranych krajach UE w pierwszym (Q1 20) i czwartym (Q4 20) kwartale 2020 r.

\begin{tabular}{|l|c|c|c|c|}
\hline \multicolumn{1}{|c|}{ Kraj } & $\begin{array}{c}\text { Zadłużenie } \\
\text { ogólem } \\
\text { w Q1 20 } \\
\text { (w mld USD) }\end{array}$ & $\begin{array}{c}\text { Zadłużenie } \\
\text { ogólem } \\
\text { w Q4 20 } \\
\text { (w mld USD) }\end{array}$ & $\begin{array}{c}\text { Wzrost zadłużenia } \\
\text { w okresie } \\
\text { Q1 20 - Q4 20 } \\
\text { (w mld USD) }\end{array}$ & $\begin{array}{c}\text { Wzrost zadłużenia } \\
\text { w okresie } \\
\text { Q1 20 - Q4 20) } \\
\text { (w \%) }\end{array}$ \\
\hline Hiszpania & 1952,7 & 2314,6 & 361,9 & 18,5 \\
\hline Francja & 4654,8 & 5532,4 & 877,6 & 18,8 \\
\hline Włochy & 3099,8 & 3650,0 & 550,2 & 17,7 \\
\hline Czechy & 207,8 & 245,9 & 38,1 & 18,3 \\
\hline Słowacja & 58,4 & 75,1 & 16,7 & 28,4 \\
\hline Węgry & 103,9 & 138,2 & 34,3 & 33,0 \\
\hline Polska & 292,3 & 408,4 & 116,1 & 39,7 \\
\hline
\end{tabular}

Źródło: opracowanie własne na podstawie danych prezentowanych przez Bank Rozrachunków Międzynarodowych https://stats.bis.org oraz Trading Economics https://tradingeconomics.com (data dostępu: 27.10.2021).

\section{Wnioski}

Pandemia COVID-19 w istotny sposób wpłynęła na rynki papierów dłużnych w Hiszpanii, Francji, Włoszech, Słowacji, Czechach, na Węgrzech i w Polsce. Początkowo, po ogłoszeniu pandemii w marcu 2020 r., obserwowano zmniejszenie zadłużenia z tytułu emisji papierów dłużnych we wszystkich omawianych krajach. Zadłużenie na koniec pierwszego kwartału 2020 r. było we wszystkich omawianych krajach niższe w porównaniu z zadłużeniem na koniec czwartego kwartału 2019 r. Począwszy od drugiego kwartału 2020 r. można było obserwować trend wzrostowy w zakresie wysokości całkowitego zadłużenia $\mathrm{z}$ tytułu wyemitowanych papierów dłużnych, co oznacza, że z kwartału na kwartał zadłużenie rosło. Wzrost zadłużenia obejmował zarówno korporacje finansowe i niefinansowe, jak też instytucje rządowe i samorządowe. 
Poczynione obserwacje pozwalają stwierdzić, że trendy obserwowane na rynkach papierów dłużnych w okresie pandemii COVID-19 nie zależały od poziomu rozwoju gospodarczego kraju, czy też stopnia rozwoju rynku papierów dłużnych. Te same trendy obserwowano zarówno w krajach wysoko rozwiniętych (Hiszpania, Francja, Włochy), jak i w krajach rozwijających się (Czechy, Słowacja, Węgry i Polska). Podobna sytuacja miała miejsce w krajach, w których wskaźnik zadłużenia z tytułu emisji dłużnych papierów wartościowych do PKB kraju oscylował wokół wartości 2 (Francja, Włochy, Hiszpania), jak i w tych, w których nie przekraczał wartości 1 (Czechy, Węgry, Słowacja i Polska). Można jednak zauważyć, iż wzrost zadłużenia $\mathrm{z}$ tytułu emisji dłużnych papierów wartościowych na Słowacji, na Węgrzech i w Polsce był gwałtowniejszy niż w pozostałych krajach. Największy przyrost zadłużenia (o 39,7\%) odnotowała Polska.

Wzrost zadłużenia korporacji finansowych i niefinansowych to niewątpliwie efekt zwiększonych potrzeb finansowych firm w czasie pandemii Covid-19 (Aldasoro i in. 2021). Dochody wielu firm uległy gwałtownym ograniczeniom, co zmusiło je do pozyskiwania dodatkowych źródeł kapitałów. Emisja papierów dłużnych stała się jednym ze sposobów pozyskania finansowania na dalsze funkcjonowanie firm na rynku i wyraźnie zyskała na znaczeniu w porównaniu z pożyczkami bankowymi (Hördahl i in. 2020).

Wzrost zadłużenia instytucji rządowych i samorządowych to również efekt zwiększonego zapotrzebowania na kapitał w czasie pandemii Covid-19. Rządy wielu państw stanęły przed koniecznością radzenia sobie ze skutkami kryzysu gospodarczego wywołanego pandemią (Bogdanova i in. 2021). Nieodzowne stało się finansowanie zakupów środków ochrony przeciwwirusowej, finansowanie szczepień, jak też pomoc materialna dla podmiotów gospodarczych, które poniosły największe straty w wyniku pandemii (w celu zapewnienia dostępności podstawowych towarów i usług na rynku, ochrony miejsc pracy, ratowania podmiotów gospodarczych przed upadkiem) (Szymańska i in. 2020, s.15).

Początkowe spadki na rynku papierów dłużnych (w pierwszym kwartale 2020 r.) to efekt wzrostu spreadów kredytowych (Aramonte i in. 2020) przy ogólnym wzroście niepewności i awersji do ryzyka (Aldasoro i in. 2021). Warunki te zaowocowały pojawieniem się wyprzedaży i dyslokacji m.in. obligacji rządowych (Schrimpf i in. 2020). Odpływy z portfela obligacji związane były z deprecjacją waluty i wzrostem krajowych długoterminowych stóp procentowych (Hofmann i in. 2020). Płynność rynku została ograniczona (Banerjee i in. 2020). Nowe emisje papierów dłużnych były niezwykle rzadkie.

Pandemie, które obserwowaliśmy w przeszłości, takie jak: SARS (2003), H5N1 (2003-2019), czy też Ebola (2014-2016) pokazały, że wpływ pandemii na gospodarkę jest długotrwały (Rungcharoenkitkul 2021). Podobnej sytuacji możemy spodziewać się w przypadku pandemii COVID-19. Jej ostateczne skutki nie zostały jeszcze określone - po pierwsze z uwagi na to, że pandemia nadal trwa, 
a po drugie z uwagi na to, że skutki długoterminowe nie są sumą skutków krótkoterminowych (Aramonte i in. 2020). Należy zauważyć, że interwencje podejmowane przez władze rządowe w poszczególnych krajach w różnych segmentach rynku (w tym w ramach rynków papierów dłużnych) mogą przynosić inne efekty w krótkim, a inne w dhugim okresie. Co więcej efekty podjętych działań mogą mieć pośredni wpływ także na inne segmenty rynku, co może doprowadzić do wielu reakcji zwrotnych, które obecnie trudno całkowicie przewidzieć.

\section{Bibliografia}

Aldasoro I., Hardy B., Tarashev N. (2021), Corporate debt: post-GFC through the pandemic, „BIS Quarterly Review”, June.

Ali M., Alam N., Rizvi S.A.R. (2020), Coronavirus (COVID-19) - An epidemic or pandemic for financial markets, Journal of Behavioral and Experimental Finance, Sep. 27. https://doi.org/10.1016/j.jbef.2020.100341

Aramonte S., Avalos F. (2020), Corporate credit markets after the initial pandemic shock, „BIS Bulletin”, nr 26.

Aramonte S., Avalos F. (2020), The recent distress in corporat bond markets: cues from ETFs, „BIS Buletin”, nr 6. https://www.bis.org/publ/bisbull06.pdf

Arslan Y., Drehmann M., Hofmann B. (2020), Central bank bond purchases in emerging market economies, „BIS Bulletin”, $\mathrm{nr} 20$.

Banerjee R., Iles A., Kharroubi E., Serena J.M. (2020), Covid-19 and corporate sector liquidity, „BIS Bulletin”, nr 10.

Bank for International Settlements (2021), Debt securities statistics, http://www. bis.org/statistics

BIS, ECB, IMF, Handbook on Securities Statistics (2015), Washington D.C., https:// www.bis.org/statistics/about_securities_stats.htm? $\mathrm{m}=6 \% 7 \mathrm{C} 33 \% 7 \mathrm{C} 638$

Bogdanova B., Chan T., Micic K., G. von Peter (2021), Enhancing the BIS government bond statistics, „BIS Quarterly Review”, June. https://www.bis.org/ publ/qtrpdf/r_qt2106c.pdf

Brodeur A., Gray D., Islam A., Bhuiyan S. (2020), A literature review of the economics of Covid-19, IZA DP, nr 13411, Discussion Paper Series, June. https://ttp.iza.org/dp13411.pdf, https://doi.org/10.2139/ssrn.3636640

Choudhry M. (2004), Corporate Bonds and Structured Financial Products, Elsevier Science \& Technology, Oxford. https://doi.org/10.1016/B978075066261-1.50054-2

ECB (2021), Pandemic emergency purchase programme (PEPP), https://www. ecb.europa.eu/mopo/implement/pepp/html/index.en.html 
European Banking Federation (2019), Answers to the FSB consultation on the evaluation of the effects of financial regulatory reforms on the provision of financing to SMEs, Brussels, https://www.ebf.eu/wp-content/uploads/2019/03/ EBF_036241-EBF-Answers-to-the-FSB-consultation-on-the-evaluation-of-the-effects-of-financial-regulatory-reforms-on-the-provision-of-financing-to-SMEs.pdf (data dostępu: 24.08.2021).

European Commission (2015), Green Paper. Building a Capital Markets Union, Brussels, http://ec.europa.eu/finance/consultations/2015/capital-markets-union/docs/green-paper_en.pdf (data dostępu: 21.08.2021).

European Commission (2021), Capital markets union 2020 action plan, https://ec.europa.eu/info/business-economy-euro/growth-and-investment/capital-markets-union/capital-markets-union-action-plan_en (data dostępu: 15.08.2021).

Heggen K., Sandset T.J., Engebretsen E. (2020), COVID-19 and sustainable development goals, Bull World Health Organisation, 98(10). https://doi. org/10.2471/BLT.20.263533

Hofmann B., Shin H.S., Shim I. (2020), Bond risk premia and the exchange rate, „Journal of Money, Credit and Banking", t. 52. https://doi.org/10.1111/jmcb.12760

Hördahl P., Shim I. (2020), EME bond portfolio flows and long-term interest rates during the Covid-19 pandemic, „BIS Bulletin”, nr 18.

Ibn-Mohammed T., Mustapha K.B., Godsell J.M., Adamu Z., Babatunde K.A., Akintade D.D., Koh S.C.L. (2021), A critical review of the impacts of COVID-19 on the global economy and ecosystems and opportunities for circular economy strategie, Resources, Conservation and Recycling, January. https://doi.org/10.1016/j.resconrec.2020.105169

Kargar M., Lester B., Lindsay D., Liu S, Weill P-O., Zúñiga D. (2020), Corporate bond liquidity during the Covid-19 crisis, NBER Working Paper, nr 27355. https://doi.org/10.3386/w27355

Khan M.A, Abdelmohsen K.Z., Nassani A., Askar S.E., Abro M., Mo. Q., Kabbani A. (2021), Financial development during COVID-19 pandemic: the role of coronavirus testing and functional labs, Muhammad Khalid Anser, Financial Innovation, nr 7(1): 9. https://doi.org/10.1186/s40854-021-00226-4

Kołuda P. (2015), Czy warto emitować dtug - analiza polskiego rynku obligacji korporacyjnych $w$ kontekście regulacji oraz globalnych trendów, http://www. cbia.pracodawcyrp.pl/files/Analiza_Piotr_Kouda.pdf

Komisja Europejska (2015), Zielona Księga, Tworzenie unii rynków kapitałowych, Bruksela, https://eur-lex.europa.eu/legal-content/PL/TXT/PDF/?uri=CELEX:52015DC0063\&rid=2

Mccauley R.N. (2020), The Fed in the Corporate Bond Market in 2021, GEGI Working Paper 041. https://doi.org/10.2139/ssrn.3676193 
Mysak J. (2012), Encyclopedia of Municipal Bonds: A Reference Guide to Market Events, Structures, Dynamics, and Investment Knowledge, John Wiley \& Sons. https://doi.org/10.1002/9781118531624

Phan D.H.B., Narayan P.K. (2020), Country responses and the reaction of the stock market to COVID-19 - a preliminary exposition, Emerg Mark Finance Trade, nr 56(10). https://doi.org/10.1080/1540496X.2020.1784719

Rebranding Capital Markets Union. A market finance action plan (2019), Report of a CEPS-ECMI Task Force, https://www.ceps.eu/wp-content/ uploads/2019/07/Rebranding-Capital-Markets-Union.pdf

Rungcharoenkitkul P. (2021), Macroeconomic effects of Covid-19: a mid-term review Monetary and Economic Department, „BIS Working Papers”, nr 959. https://doi.org/10.1111/1468-0106.12372

Schrimpf A., Shin H., Sushko V. (2020), Leverage and margin spirals in fixed income markets during the Covid-19 crisis, „BIS Bulletin”, nr 2. https://doi. org/10.2139/ssrn.3761873

Somerset B. (2013), Treasury Finance and Development Banking: A Guide to Credit, Debt, and Risk, John Wiley \& Sons, New Jersey.

Szymańska J., Szczepanik M., Płóciennik S. (2020), Działania UE wobec pandemii i jej konsekwencje dla integracji, [w:] P. Sanal (red.), Konsekwencje pandemii COVID-19 dla stosunków międzynarodowych, Polski Instytut Spraw Międzynarodowych, Warszawa.

Topcu M., Gulal O.S. (2020), The impact of COVID-19 on emerging stock markets, „Finance Research Letters”, nr 36: 101691. https://doi.org/10.1016/j. frl.2020.101691

\section{Summary}

The impact of the COVID-19 pandemic on the debt securities market - an analysis based on the example of selected countries

The aim of the study is to present the impact of the COVID-19 pandemic on the debt securities markets in seven selected European countries, i.e. Spain, France, Italy, Slovakia, the Czech Republic, Hungary and Poland. The analysis is based on the observation of statistical data on debt securities presented by the Bank for International Settlements. The period covered by the analysis is 2020 . The volume of debt due to debt securities in selected countries was analyzed, broken down into debt securities issued by financial corporations, non-financial corporations and government and local government institutions. Trends in changes in debt are also shown based on the size of overall debt securities in the countries under review. 
Quarterly data was used to illustrate changes in the debt securities market during the COVID-19 pandemic more accurately. The analysis of the topic allows us to conclude that the COVID-19 pandemic had a positive impact on the development of the debt securities market in the discussed countries. All countries registered an upward trend in the amount of total debt arising from debt securities issued. The increase in indebtedness concerned both financial and non-financial corporations, as well as central and local government institutions. The observed trends did not depend on the level of economic development of the country or the degree of development of the debt securities market.

Keywords: debt securities, Covid-19, pandemic, Poland, Spain, France, Italy, Czech Republic, Slovakia, Hungary 